\title{
محمد عبده واتجاهـ الأدبي في التفسير
}

\author{
M. Sihabuddin \\ UIN Walisongo Semarang \\ sihabudin@walisongo.ac.id
}

\begin{abstract}
This research strengthens the findings of the previous research which stated that Muhammad Abduh used literary paradigm in his Tafsir. Abduh, although he was known as a man of letters but there is a statement that it does not mean that Abduh's Tafsir entirely stands on the methods and literary paradigm. Due to this reason the study is purposed. The findings of this research show that Abduh's interpretation toward the Qur'an is not much different than what is done by the contemporary interpreters such as Amin Al-Khulli. The literary approach used by Abduh in interpreting the Qur'an it could be reviewed from linguistic description given upon words in the Qur'anic verses and the aspect of the history of the development of the meaning of those words. In addition, Abduh's literary approach is also identical to rationalism tradition in the world of the Qur'anic exegesis scholarship. This caused Abduh to be accused as of the leftist Mu'tazilah. However, by using the inter-textual method, this research concludes that the allegation is not true.
\end{abstract}

Keywords: Muhammad Abduh, al-tafsir, ai-ittijah al-adabi

أ. أ. التمهيد

لقد حاول محمد عبده إلى أن يجعل تفسير القرآن هداية للحياة الإنسـانية والمعالجة فيما واقع في العالم الإسلامي العصري من جمود وشلل يسيّبان الركود والانحطات. هذا بجانب إلى أن له رغبةً فائقة

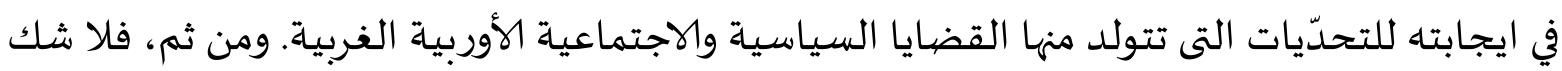
لو أنه لا يشتغل بكشف معانى النصوص القرآنية استجابةً للفكر الإسلامي الناهض، وحثّه على مداومة النهوض فحسب، بل كانت عنايته بالقضية كيف يساير تفسير القرآن الكريم مع مظاهر العلوم التى العي

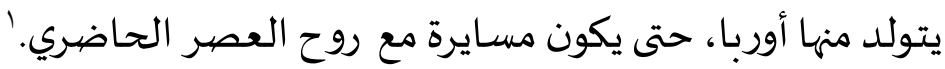

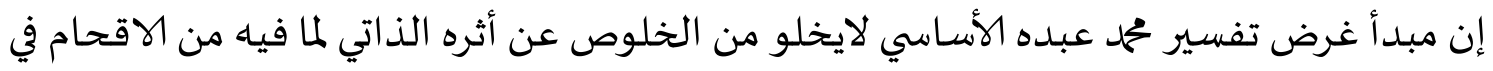
عملية تفسير معانى النصوص القرآنياة، كما وقع في العصر الحاضر بظهور اتجاه التفسير العلمي لطنطاوي الجوهري. وقد انتقده أمين الخولي, وهو زعيم اتجاه التفسيرالأدبي في العصر الحديث.

\footnotetext{
${ }^{1}$ Khoiru an-Nahdiyyin, Metode Tafsir Sastra, (Yogyakarta: Adab Press, 2004), 124-125.
} 
ولعل ما يمتاز تفسير محمد عبده عن غيره أنها مهما كان يتوسع في تفسيره ويحرص على "كشف المعانى" في تفسيره فإناه لا يتجاوز عن حدّ النص نفسـه. وقد ذكر بعض المثقفين الإسلاميين، نحو ناصر حامد أبو زيد، نور خالص ستياوان، وغيرهما أن الغرض الأول في تفسير محمد عبده وهو الاهتداء بالقرآن

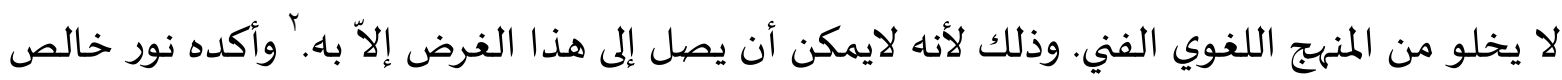
ستياوان بأنه -على الرغم من أنهاه مهما انطلق إلى الهـداية كالغرض الأول في تفسيره - فإنه لايتجاوز عن المنهج اللغوي الفني. ويعرف ذلك بما صرح به في تفسيره من مداومة العثور على أصل معنى الكلمة اللغوي من وقت نزول القرآن إلى وقت ما فسر معانى مفردات القرآن. بّل صرّح نور خالص بأن نشأة المنهج الأدبي في التفسير العصري قد بدأ بذوره على يده. ؤومثال ذلك ما ذهب اليه باحثوا الدراسـات

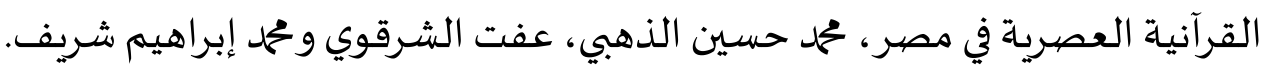

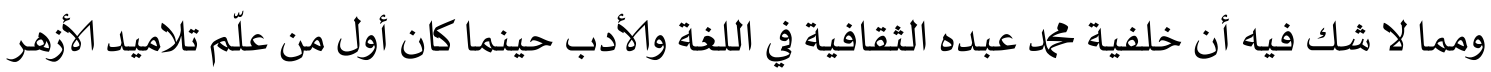
الشريف علمَ البلاغة من كتابي عبد القاهر الجرزاني: "أسرار البلاغة" و "دلائل الإعجاز"، لها أثر قوي في اتجاهه الأدبي في التفسير. وكذا عنايته بشرح نهج البلاغة للسيد علي كرم الله وجهه تؤيد مظاهر ثقافية محمد عبده في اللغة والأدب. وبهذا، فلا يخفي على علماء الأزهر لو أن محمد عبده مشههور بزعيم اللغة والأدب العصري في الأزهر الشريف. وهو الزعيم الذي برز في عصر الانحطاط والتأخر. وعلى الرغم من ذلك كله، قلّ ما بحث الباحثون عن محمد عبده واتجاهـ الأدبي في التفسير، بل بهري كثيراما بحث الباحثون عن اتجاهـ العقلي والاجتماعي والسياسي. وهذا معقول، إذ ظلّت هذه الاتجاهي في تفسيره من أبرز أفكاره عندهم.

\section{ب. محمد عبده وثقافته الأدبية.}

إن أدبية محمل عبده قال محمد مصطفى المراغي يتحدث عن دروس أستاذه محمد عبده : "وكانت

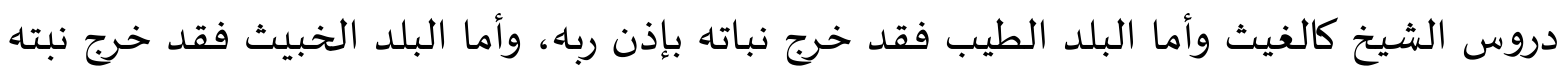
نكدا، وكانت دروسه مثلا عليا في طريقة الإلقاء والتفهيم، وفي العبارات الفصيحة المتخيرة الناقدة إلى القلوب وكانت دائرة معارف يجد اللغوي فيها حاجته، والفقياء رغبتاه والمتكلم بغيتاه، ويجد العلماء الاجتماع فيها تطبيق آي القرآن على معارفهم، وكانت صرخاته المدوية منبهة للغافل ومحركة اللجامد،

${ }^{2}$ Khoirun An-Nahdiyyin, Metode Kajian..., 127.

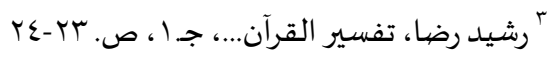

${ }^{4}$ M. Nurkholis Setiawan, Al-Qur'an Kitab Sastra Terbesar, (Yogyakarta: eLSAQ Press, 2005), 29.

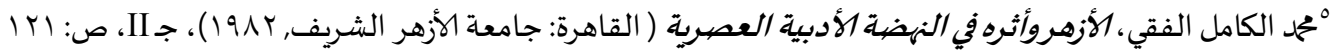


وكانت عاصفة قوية هزت الأشجار الباسقة القوية فسقطت أوراقها الذابلة ثم أورقت، أما الشجيرات

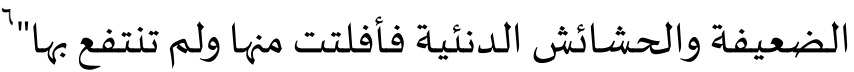

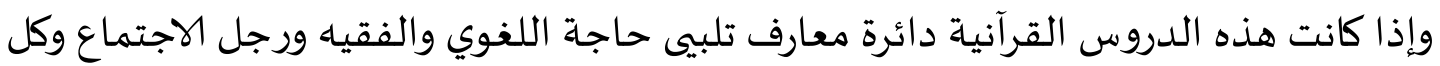

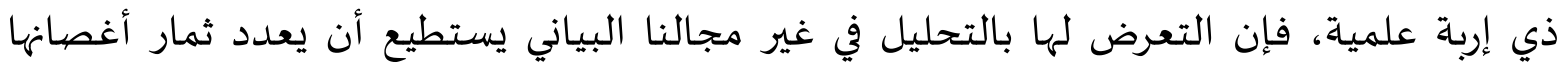

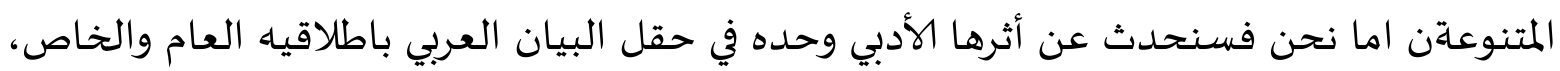

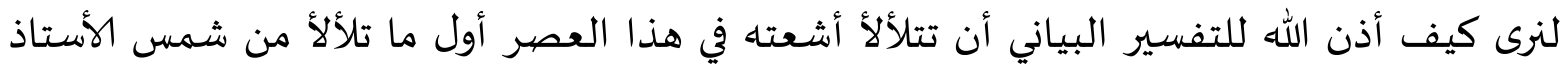

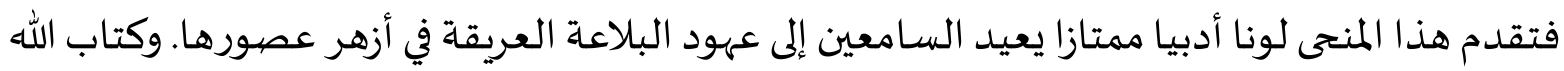

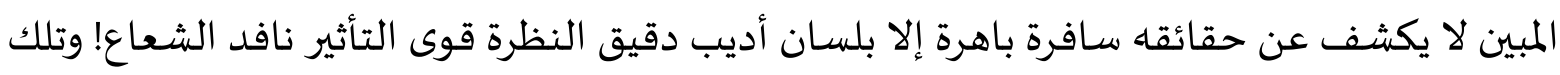
من سمات محمد عبده.

لقد درس محمد عبده الفلسفة والمنطق على يد جمال الدين في لقائهما الأول بمصر مع الصفوة الصفا

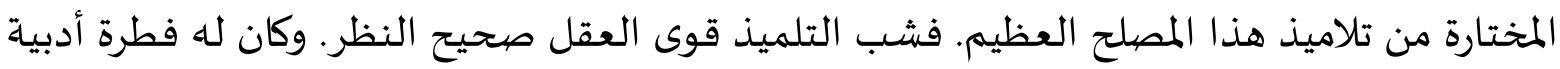

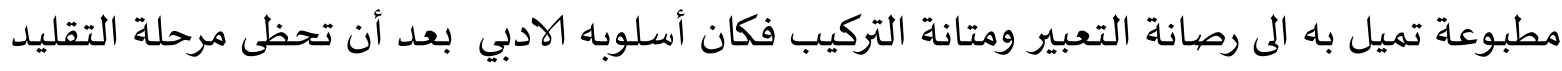

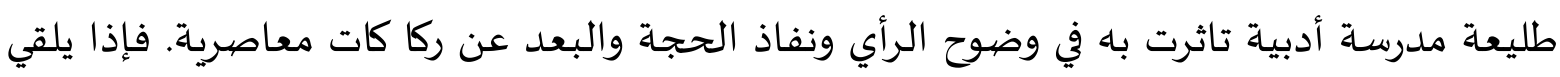

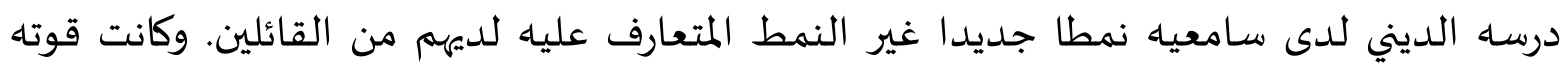

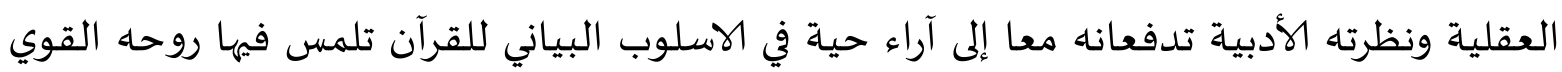

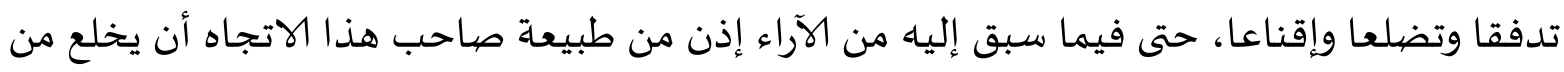

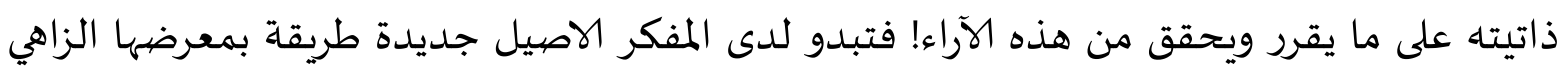

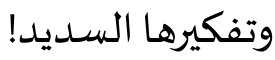

إن منزلة محمد عبده في النثر العربي المعاصر تقوم بمنزلة البارودي في الشعر المعاصر، فكلا

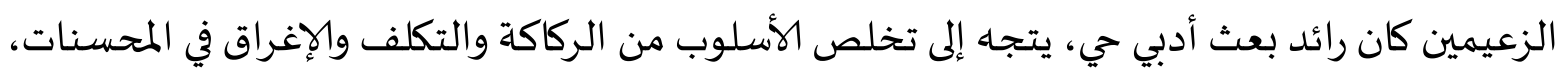

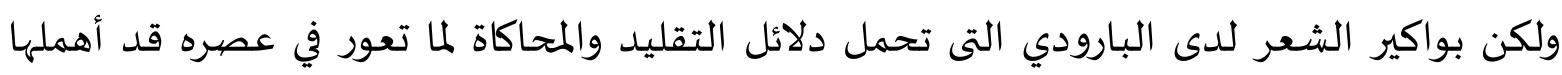

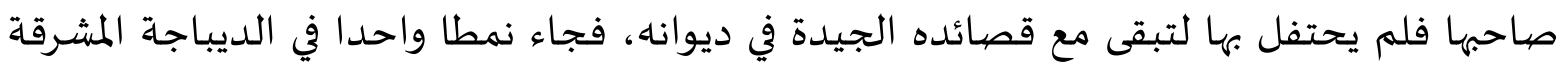

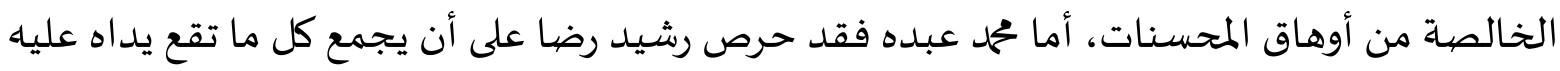

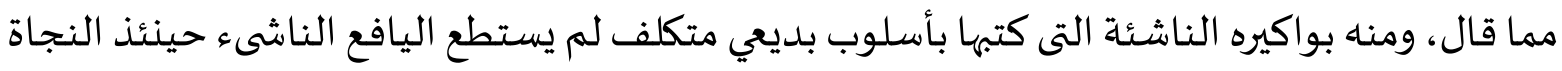

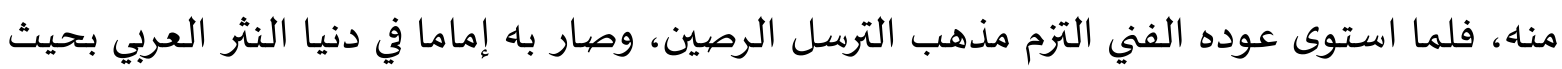

Tرجب البيومي، خطوات التفسيرالبياني للقرآن الكريم، (الأزهر: مجمع البحث الإسلامية، الY I )، ص. YNV

Teosofia: Indonesian Journal of Islamic Mysticism, Volume 5, Number 1, 2016 
امتد أثره إلى أناس لم يردوا مورد الثقافة الدينية في الأزهر، من أمثال قاسم أمين ولطفي السيد وأحمد فتحى زغلول ممن حاكوا محمل عبده عن الاقتناع.

وذكر رجب البيومي أن أسلوب محمد عبده في تفسير القرآن كان أحد عنداصر التجديد التحيد الأدبي المعاصر، إذ ما كاد يظهر في وضوحهه وتدفقها وبعده عن طريقة الحواشي والتقريرات، حتى احتذاه كل معالج للمسائل الدينياة من تفسير وإرشاد وإصلاح اجتماعي يستند إلى مقررات الشرع. بحيث أصبح كل كاتب ديني ينحو نحوه محاولا جهده أن يتعلق باه، وبحيث كان تلاميذ محمد عبده لايقتصرون عمن سعدوا بلقائه بل يمتدون إلى قارئى آثاره ممن أتوا بعده. فإذا رأينا نفخات عبقة لدى عبد العزيز الجاويس ومحمد الحضري، وعبد الوهب النجار، ومحمد رشيد رضيا، ومحمل مصطى المراغي وإبراهيم الجبالي ومصطفى عبد

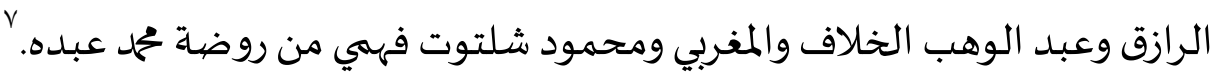

كان محمد عبده قد التزم الإشراق الآخذ في لفظه، والترتيب المنسق في تفكيره والتحديد المحقق في معانيه عناصر واضحة الطابع في تفسيره البياني، وإذا لم يعد الشرح البلاغي لدياه ولدى أتباعاء الكثيرين يدور في أكثر مناحياه حول تحديد التشبيه والاستعارة الكناية في دائرة البيان أو يتقيد في أكثر أموره بمصطلحات الفصل والوصل والخبر والإنشاء في دائرة المعانى فأصبح هذا الشرح البلاغي يمس ذلك وأكثر من ذلك في دائرة الأسلوب الأدبي الواضح بأسراره السافرة بحيث تطالعك روح البلاغة وجوهرها مطالعة تشبيعك وترضيك، وجاء تلاميذه يتمسكون بمنهجه، وارتضوا طريقته فوصلوا إلى عقول السامعين والقارئين. وأصبح لدينا من التفسير البياني المعاصر آثار رائعة تستأهل الدراسـة، لأن كل مصلح يستند إلى آيات القرآن ولن تكون الآيات صريحة الدلالة إلا إذا فسرت واتضع بها الدليل، وكل آية تحمل من أفانين البيان البلاغي ما تمتلىء باه العقول القلوب. ومن هنا، كثرت لدينا الذخيرة البيانية في التفسير المحتذى طريقة محمد عبده.

ويمكننا ان نسفيد من بيان شخصية محمل عبده وأدبيته أن ما عنده من القوة الأدبية يجعله

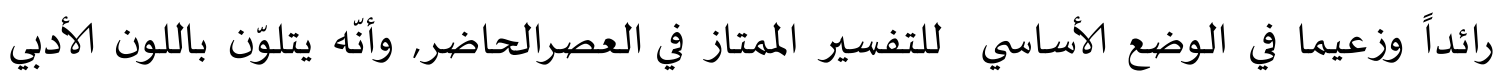
الاجتماعي. لاجل معالجة النصوص القرآنية معالجة تقوم أوّلا وقبل كل شيء على إظهار مواضع الدقة في التعبير القرآني, ثم بعد ذلك تصاغ المعانى التى يهدف القرآن اليها في أسلوب سيق أخاذ, ثم

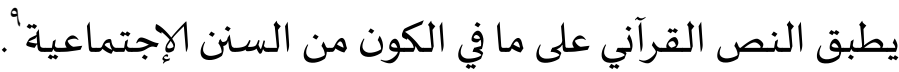

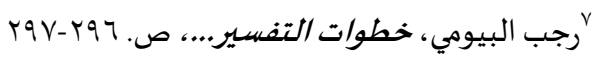

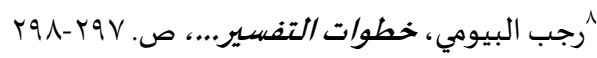

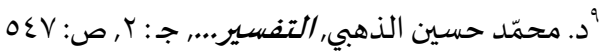




\section{ج. محمد عبده وخطواته الأدبية في التفسير}

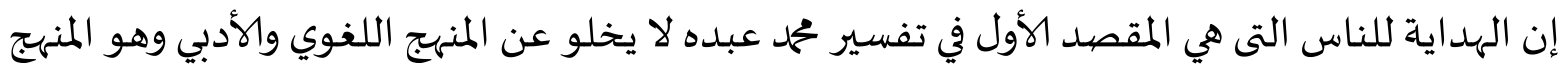

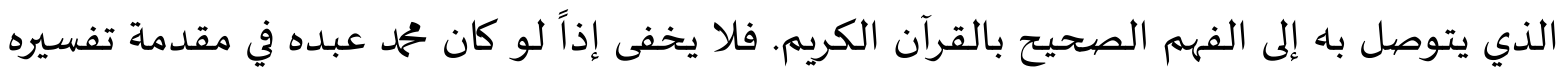

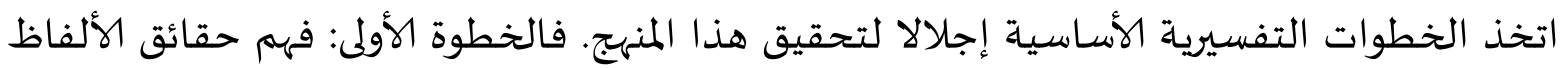

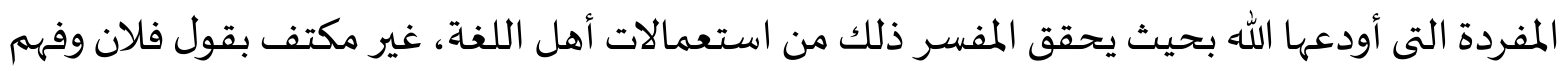

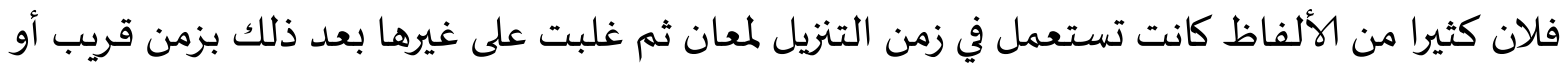

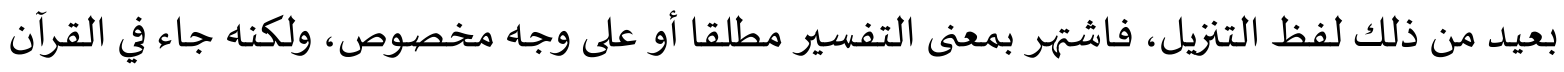

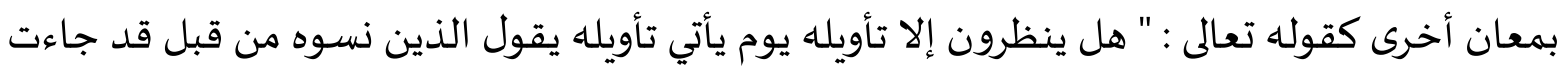

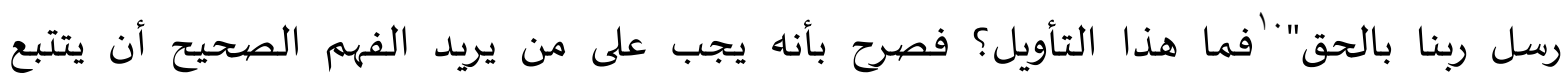

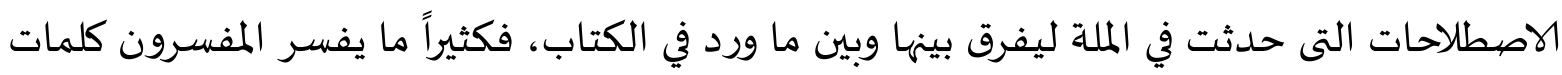

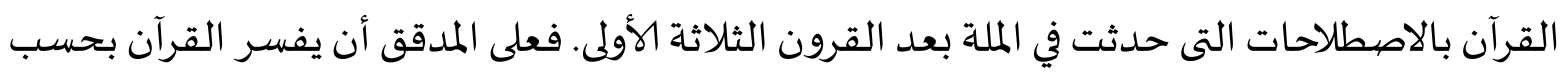

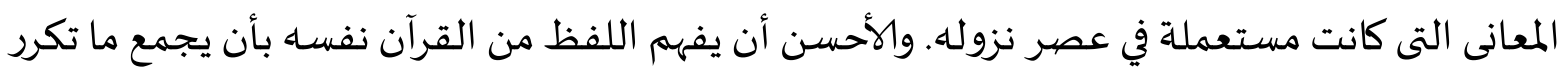

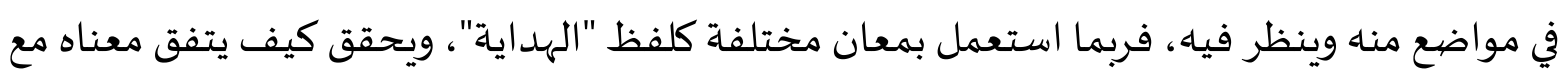

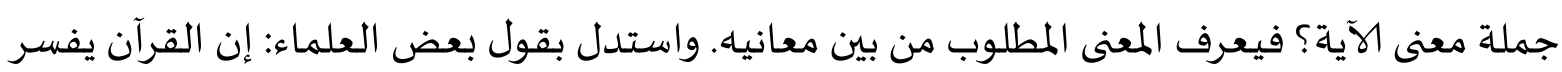

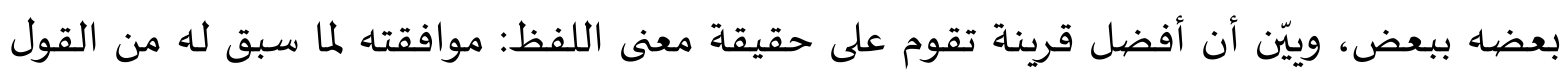

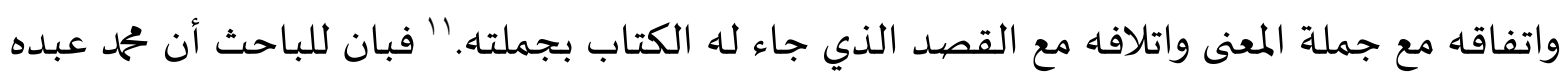

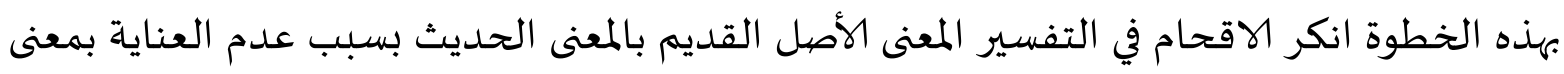

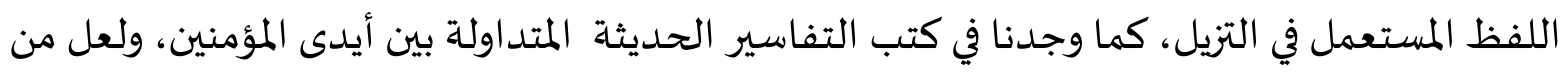
أبرز مظاهر هذه التفاسير التفسير العلهي.

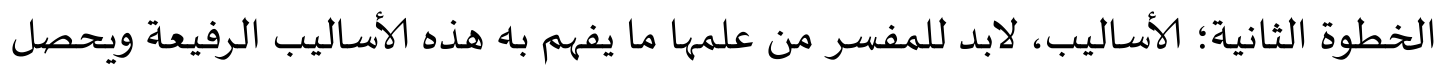

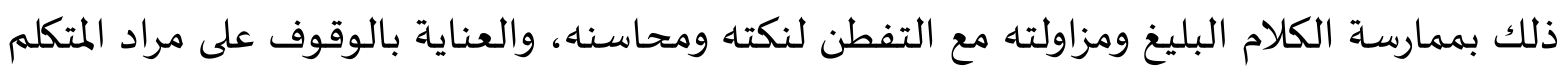

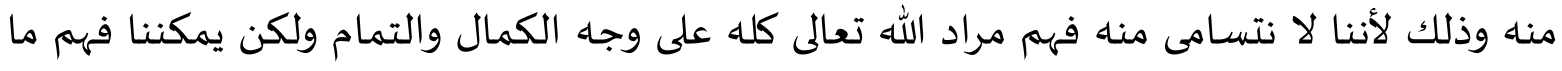

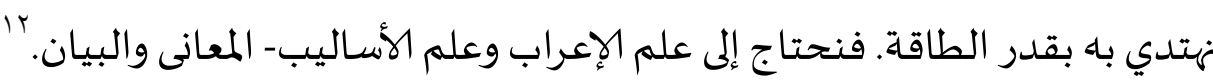

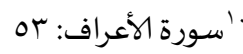

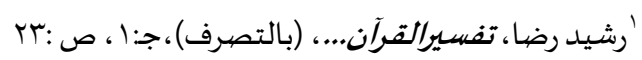

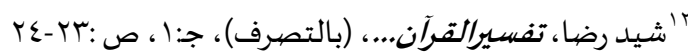

Teosofia: Indonesian Journal of Islamic Mysticism, Volume 5, Number 1, 2016 
الخطوة الثالثة؛ علم أحوال البشر، وذلك لأن من اراد أن يبحث الكتاب لا بد له من العناية بأحوال البشر من نشأتها وتطورها ومنشأ اختلاف أحوالهم، من قوة وضعف وعز وذل وعلم وجهل وإيمان وكفر، ومن العلم بأحوال العالم الكبير من علوية وسفلية. ويحتاج في هذا إلى فنون كثيرة من

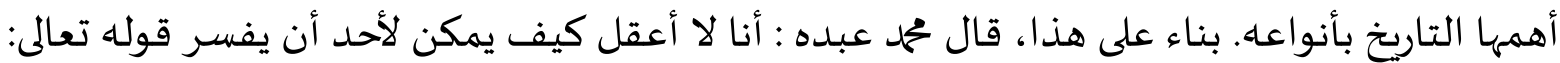

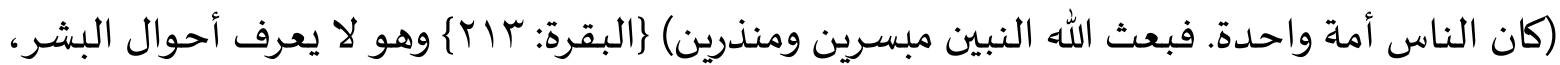
وكيف اتحدوا، وكيف تفرقوا؟ وما معنى تلك الوحدة التى كانوا عليها؟ وهل كانت نافعة أم ضيارة؟ وماذا كان من آثار بعثة النبيين فيهم.

الخطوة الرابع؛ العلم بوجه هداية البشر كلهم بالقرآن. فيجب على المفسر القائم بهذا فرضيا كفائيا: أن يعلم ما كان عليه الناس في عصر النبوة من العرب وغيرهم، لأن القرآن ينادى بأن الناس كلهم كانوا في شقاء وضلال، وأن النبي صلى الله عليه وسلم بعث به لهدايتهم وإسعادهم. وكيف يفهم المفسر ما قبحته الآيات من عوائدهم على وجه الحقيقة أو مايقرب منها إذا لم يكن عارفا بأحوالهم وما كانوا عليه؟ هل يكتفى من علماء القرآن دعاة الدين والمناضلين عنه بالتقليد، بأن يقولوا تقليدا لغيرهم. إن

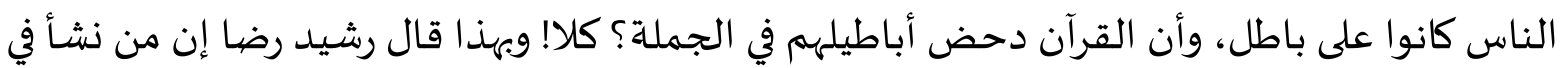
الإسلام ولم يعرف حال الناس قبله يجهل تأثير هدايته وعناية الله يجعله مغيراً لأحوال البشر ومخرجا

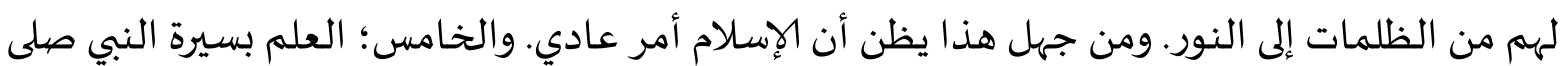

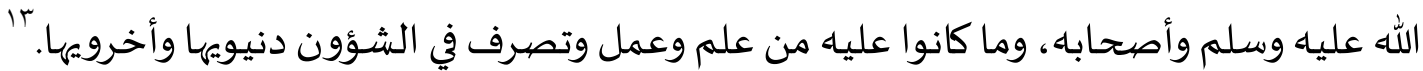
إذا أمعنا النظر إلى الخطوات التفسيرية لمحمد عبده وجدنا أن لها علاقة وثيقة بالأساسيين، الأول؛ اللغة في سياق التاريخ، لأن اللغة تستعمل في عصر التنزيل. والثانى؛ العالم، لأن اللغة لها وظيفة في تحقيق الحكم الذي يحرك العالم على شكل طبيعي او اجتماعي في عملية سيرة تاريخية. فالنص عند محمد عبده بخطواتا المنهجية هو التركيب اللغوي الذي له المعنى في سياق التاريخي والاجتماعي فلا يخلو في نفس الوقت، من اجاده في اتخاذ المعنى الخارج من السياق التاريخي-الاجتماعي. ولكن المعنى الذي هو خارج السياق التاريخي-الاجتماعي لا يلتزم بالاقحام في ذلك المعنى إلى التركيب اللغوي الذي لـ المعنى من

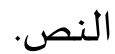

ومن هنا، كان محمد عبده يستمد بالأدوات التفسيرية التقليدية (علم المعانى والبيان) لكشف معانى النص، واطلق عليها بـعلم الأسلوب". فيبدل المصطلاح القديم بالمصطلاح الحديث على الشكل 
المجازي. وكان هذا البدل نفسه له معنى خاص، فالجديد لا يغير القديم ولا يذهبه، بل يكون كل منهما

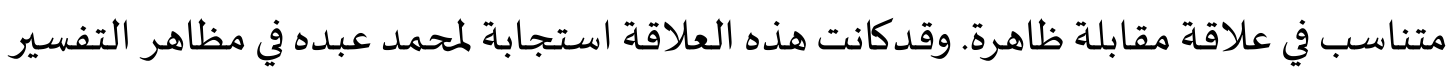
القرآني. وكانت محاولة محمد عبده في دراسة التفسير الأدبي وتبعها أمين الخولى (190 (1977) ) تكميلا لها حتى

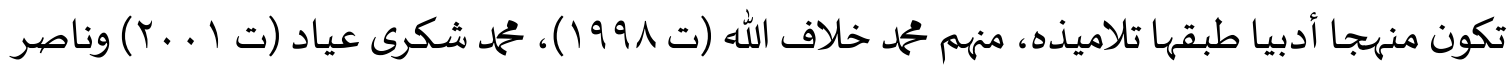

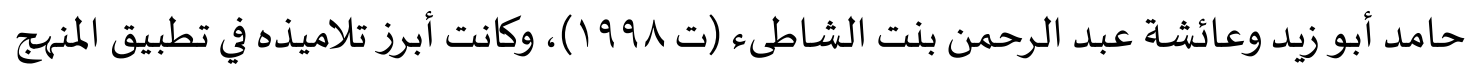

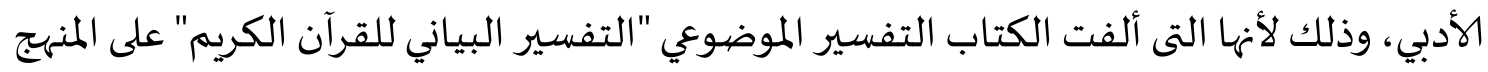

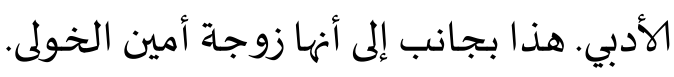

\section{د. تفسير محمد عبده في معانى مفردات القرآن}

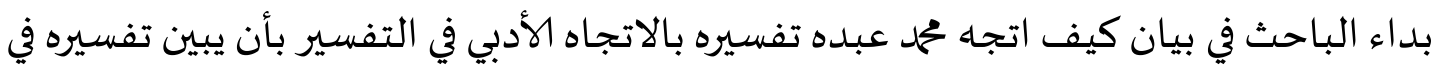

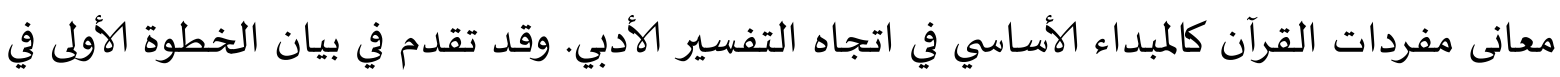

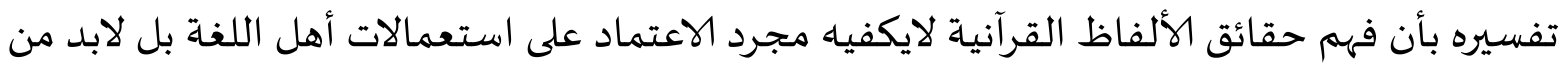

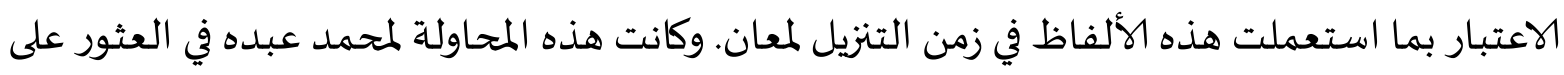

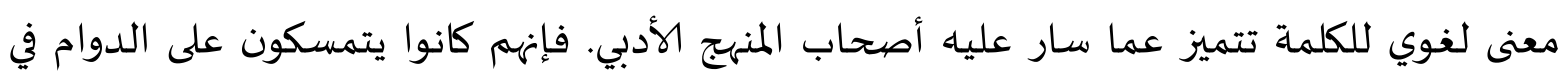

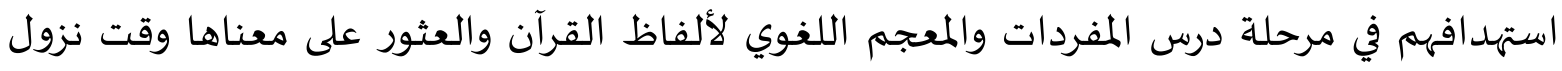

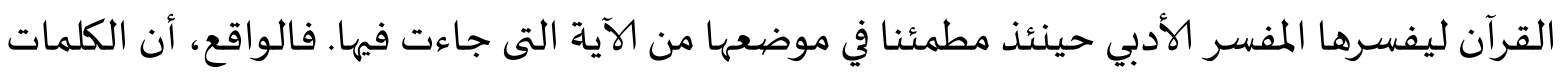

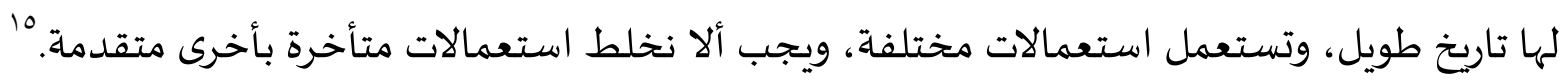

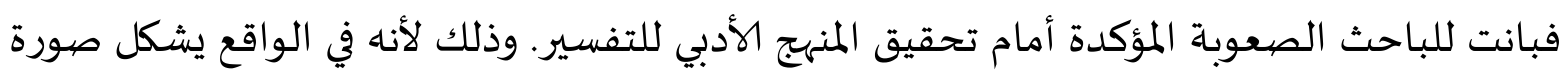

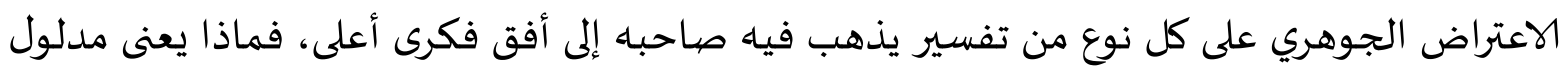

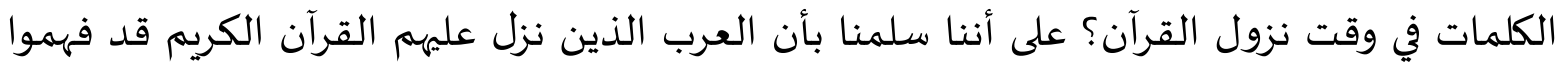

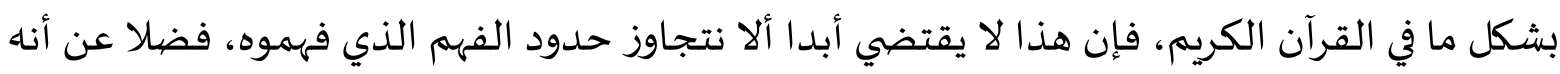

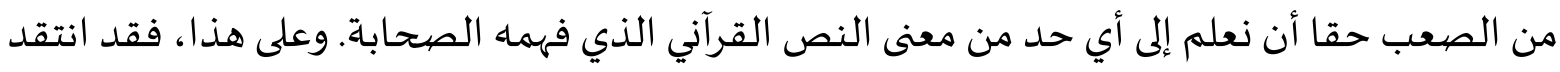

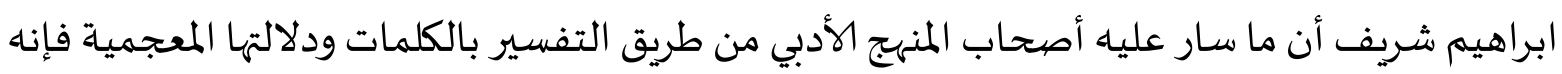

\footnotetext{
${ }^{14}$ Khairu an- Nahdiyyin, Metode Tafsir..., 32
}

$$
\text { |'براهيم شريف، اتجاه التجديد.... ص: OrV }
$$


مطرب وغير صيحيح، لو صدر المفسر الأدبي في هذا الاعتراض من تصيور أن ألفاظ اللغة - أية لغة إنما

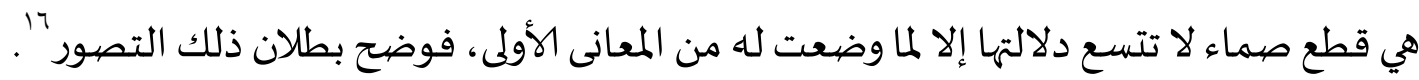

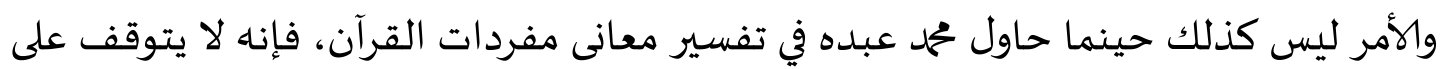
السير في طريق التفسير بالكلمات ودلالتها المعجمية كبداية الطريق إلى تفسير النص. بل تكون الفكرة التى يحددها السياق هي البداية الحقيقة لفهم اللفظ. وذلك لأن التفسير عنده لابد من أن تكون فيه العلاقة الوثيقة بين الفكرة العامة واللفظ. ويبرهن على ذلك أن محمد عبده قد اتخذ لنفسـه في اجراء غالب نقده لمفسري العصور الوسيطة خاصية الجلالين على قاعدة السياق، فهذه هي التى لعبت دورا خطيرا في تفسيره وصاحبه " فإن أفضل قرينة تقوم على حقيقة معنى اللفظ - كما قال محمد عبدهموافقته لما سبق له من القول، واتفاقه مع جملة المعنى، واتلافه مع القصد الذي جاء له الكتاب

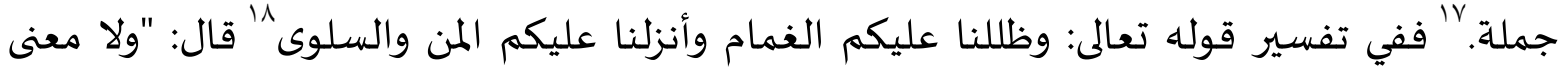
لوصف الغمام (هنا) بالرقيق كما قال المفسر الجلال وغيره، بل السياق يقتضى كثافته، إذ لايحصل

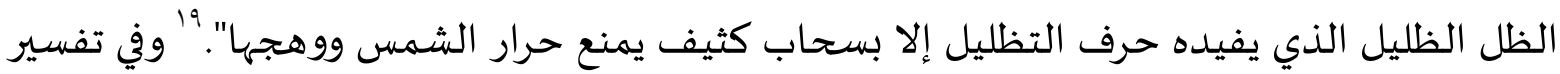
قوله تعال : "بلى من كسب سيئة وأحاطت باه خطيئته" ‘ قال محمد عبده"للسيئة" أي هنا إطلاقها، وخصها مفسرنا الجلال وبعض المفسرين بالشرك، وقال: "ولو صح هذا لما كان قوله تعالى: (وأحاطت باه

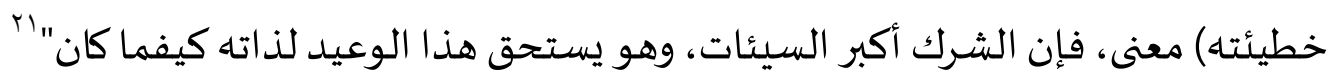

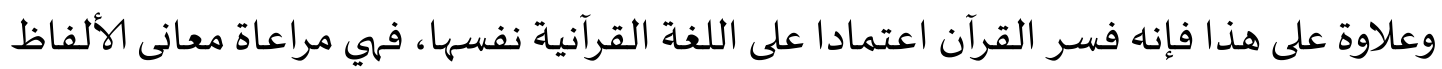
القرآنية كما كانت في اللغة عند نزول والوحي والاحتراس مما طرأ على معانيها من تطور واستعمالات، ومراعاة القواعد النحوية والبلاغة خاصة قاعدة ألا يخرج اللفظ من الحقيقة إلى المجاز إلا بقرينة كافية

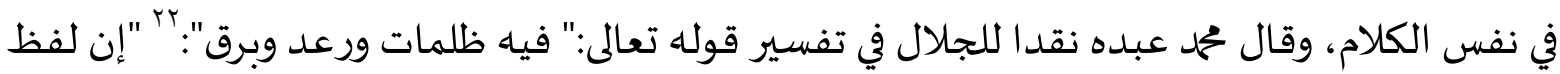

$$
\begin{aligned}
& \text { "'براهيم شريف، اتجاه التجديد..... ص: ص:بrه }
\end{aligned}
$$

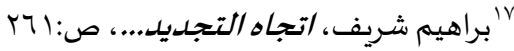

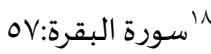

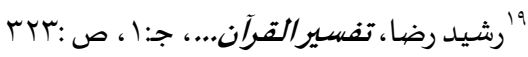

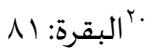

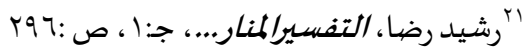

"rr وقد صرح محمد عبده في تفسير الاية 19 في سورة البقرة تعليقا على الجلال السيوطي حيث إنه قال: إن الرعد ملك أو صوته، والبرق

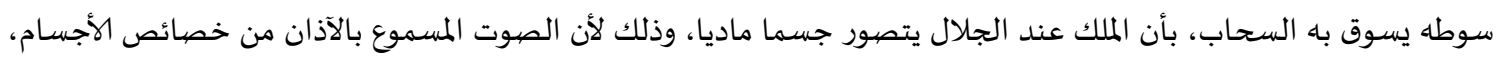

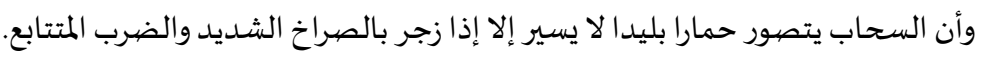




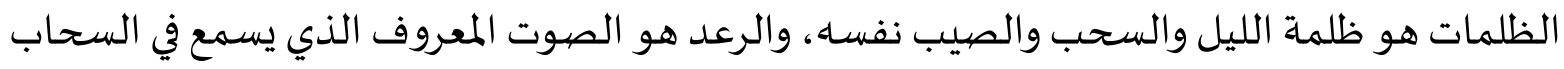

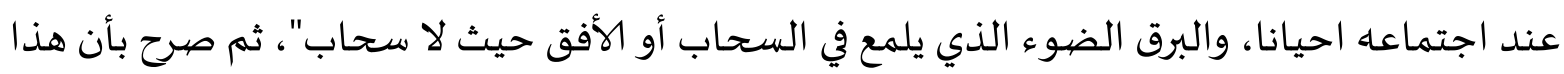

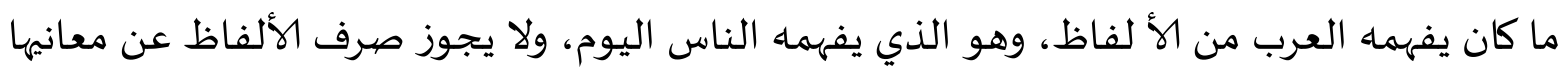

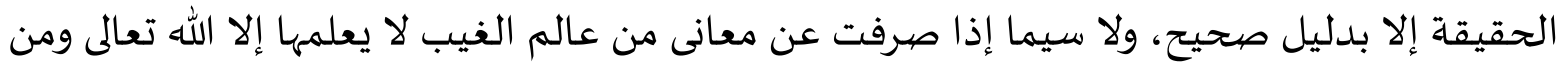

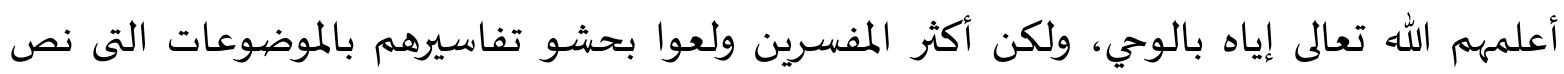

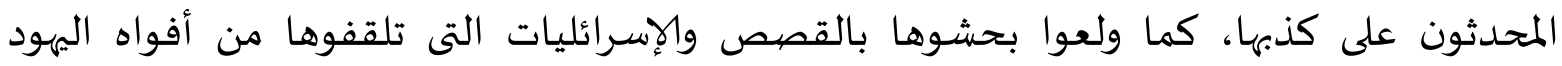

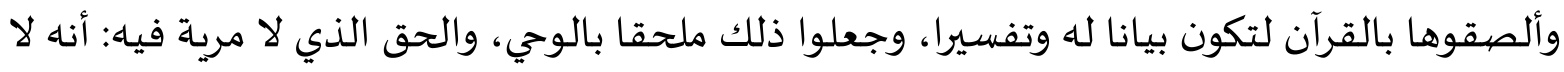

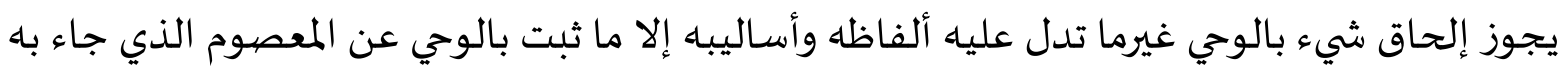

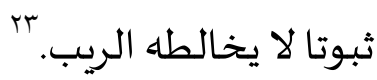

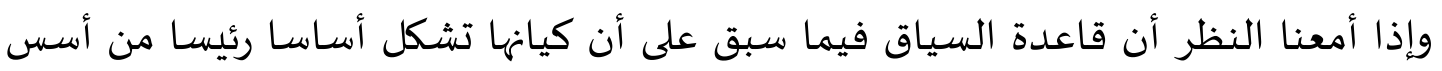

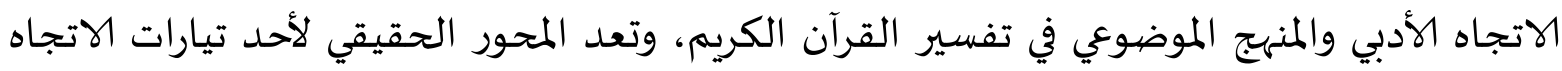

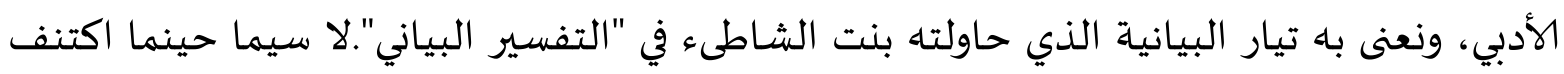

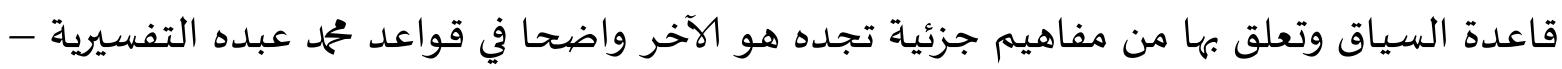

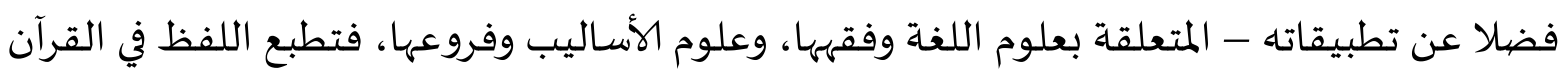

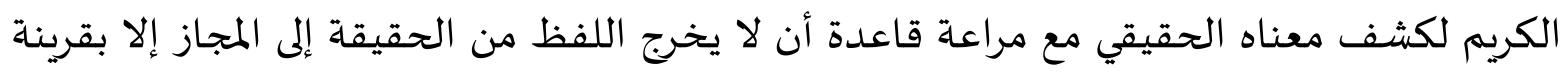

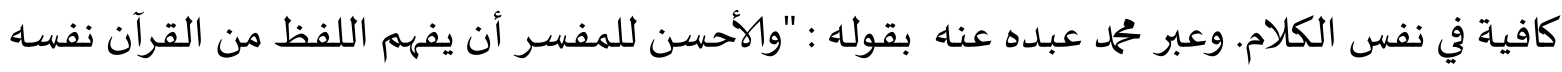

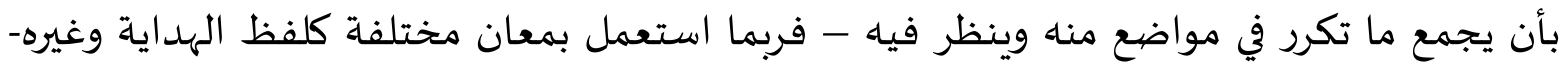

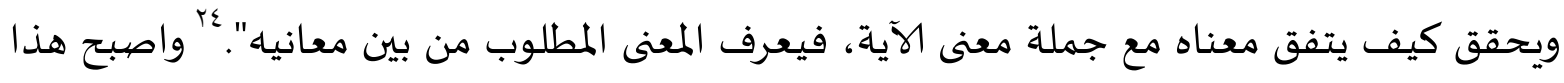

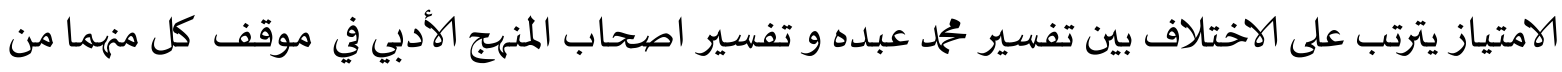

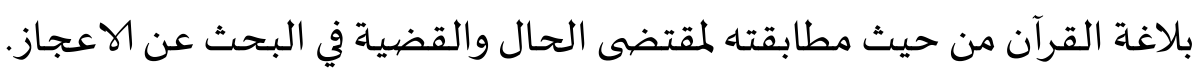

\section{هـ مهمد عبده وقضية الإعجاز.}

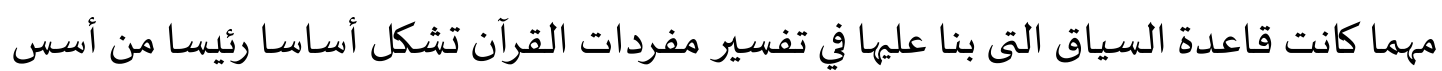

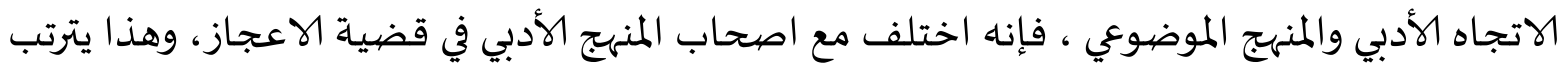

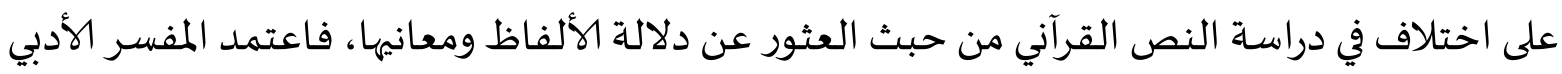

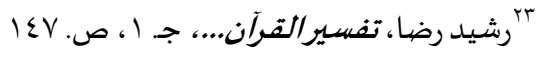

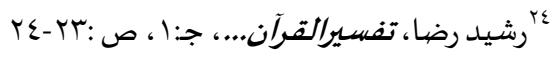

Teosofia: Indonesian Journal of Islamic Mysticism, Volume 5, Number 1, 2016 
على أن المتفق عليه هو أن بلاغاة أي كلام هي مطابقته لمقتضى حال المخاطبين، وهل يكون القرآن وهو

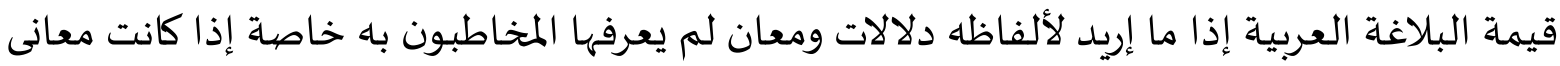
علمية لم تعرفها الدنيا إلا بعدما جازت آمادا فسيحة وجاهدت جهادا طويلا ارتقى به عقلها وعلمها.

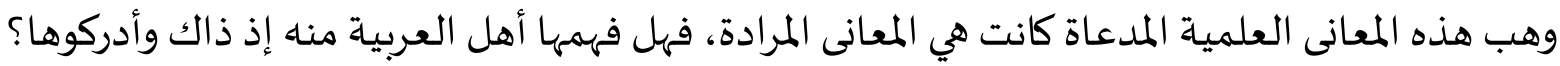

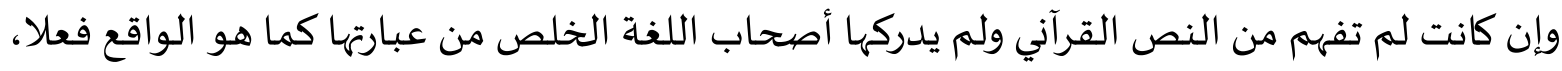

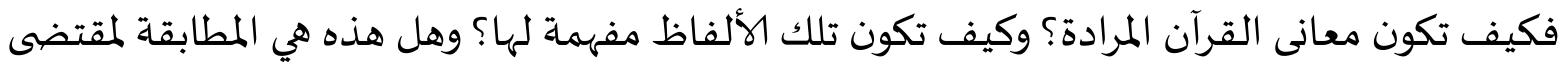
الحال؟ فيف تكون

إن هذا الاعتراض البلاغي الأدبي لا يكاد يضيف جديدا عن سابقيه اللغوي غير المسألة المطابقة،

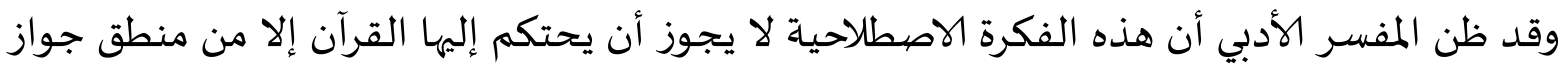

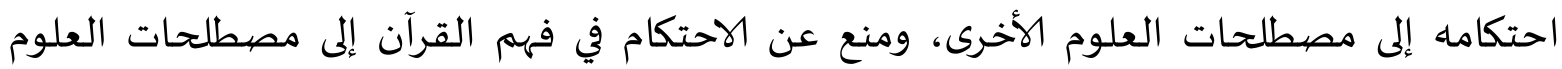

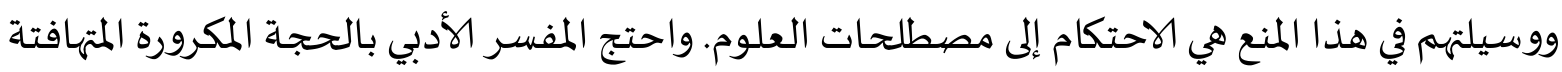

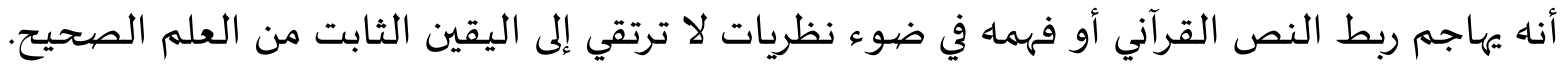
واتخذ التفسير العلمي موضع هجومه بأنه التفسير الذي يحكم الاصطلاحات العلمية في عبارة القرآن

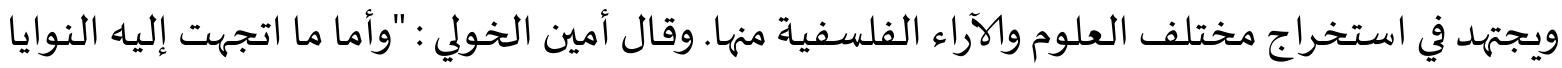
الطيبة من جعل الارتباط بين كتاب الدين والحقائق العلمية المختلفة ناحية من نواحى بيان صدأدقها

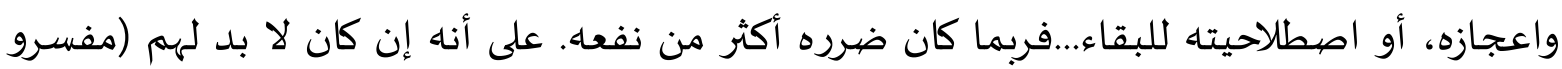

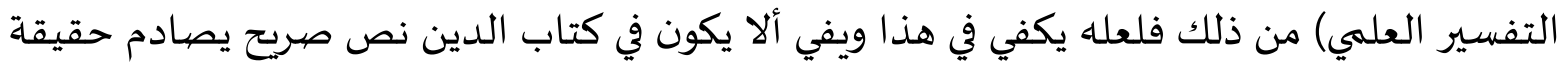

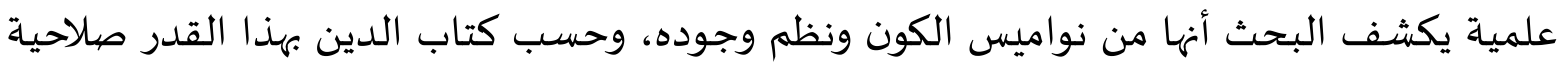
للحياة ومسايرة للعلم وخلاصا من النقد...وخير لأصحاب هذه الرغبات الذين يبينون الصدق والاعجاز أو الصلاحيات لكتاب الدين بهذا النحو من التفسير العلمي - خير لهم أن يقدروا مثل هذا الهاعتبار،

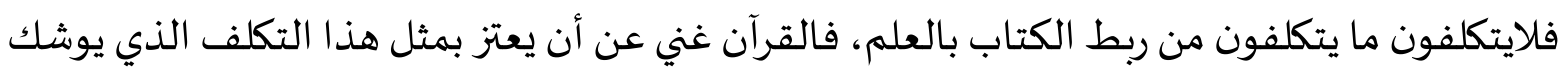

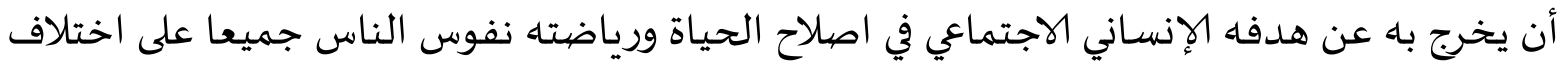

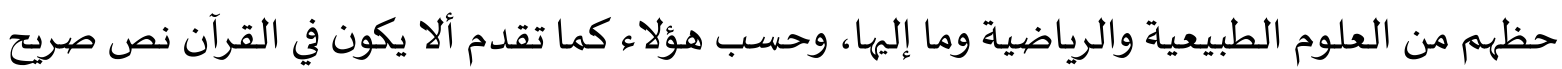

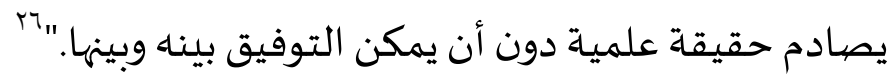

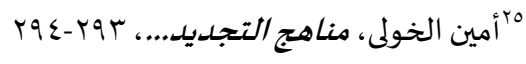

$$
\begin{aligned}
& \text { Trأمين الخولى، مناهج التتجديد....، ص: }
\end{aligned}
$$


وإذا ما تسـامحنا في هذه النقطة، فمن حقنا أن نتساءل: إذا كانت المطابقة تعنى ألا يخرج مدلول

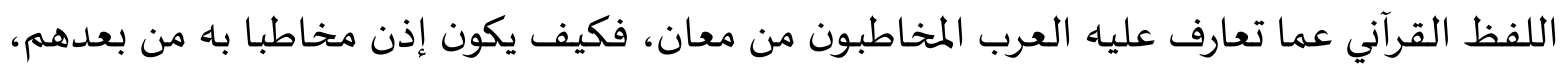

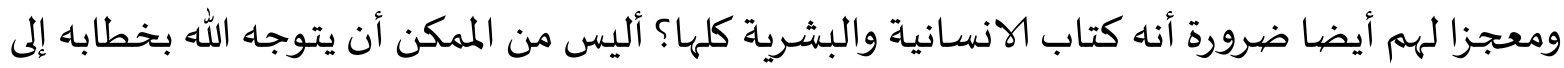

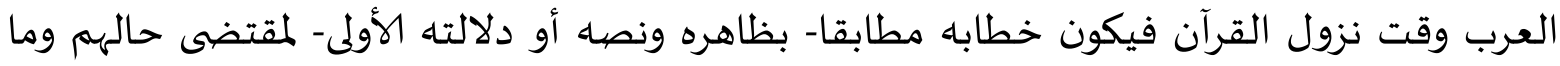

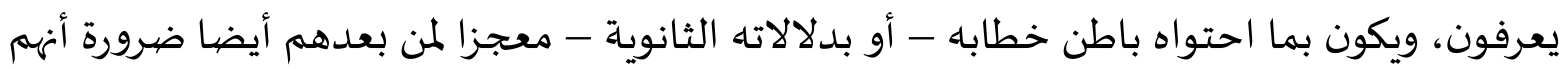

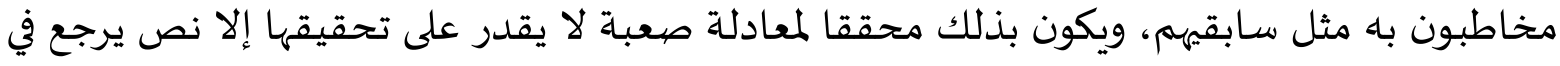

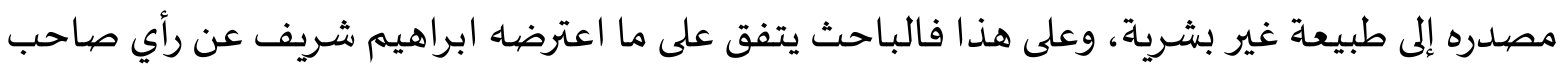
المنهج الأدبي.

وامتاز تفسير محمد عبده عن صاحب المنهج الادبي بتصريحها فكرة التفسير العلمي لا سيما في تطبيقها على الناحيتين التاريخية والعلمية، فمعرفة الكون وسنن الله تعالى فياه عند محمد عبده، مما يعين على فهم القرآن وسائر العلوم من الرياضيات والطبيعيات وغيرها، لا يضر شيء منها بالدين، بل يقويها

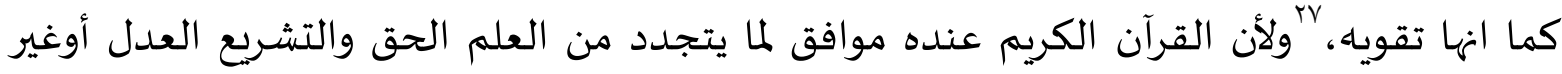

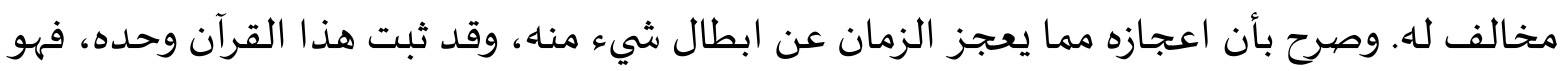

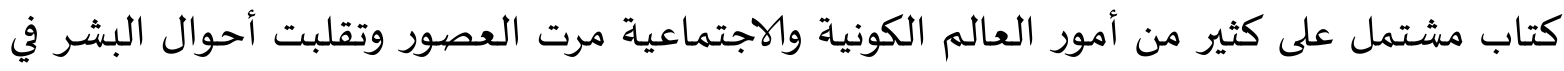

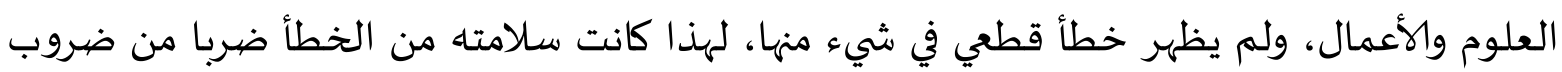

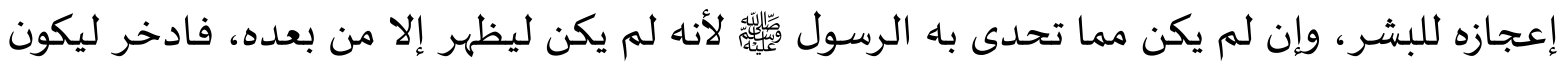

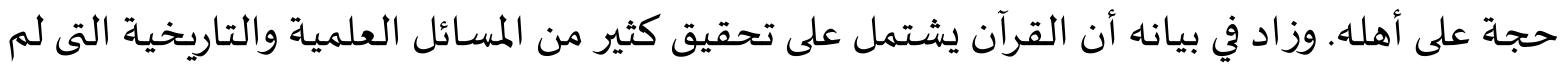
تكن معروفة في عصر نزوله، ثم عرفت بعد ذلك بما انكشف للباحثين والمحققين من طبيعة الكون

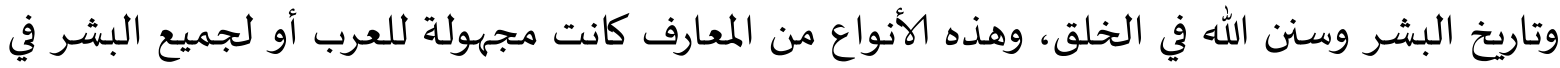

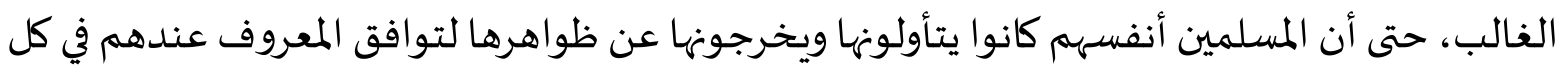

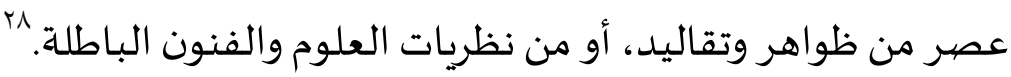

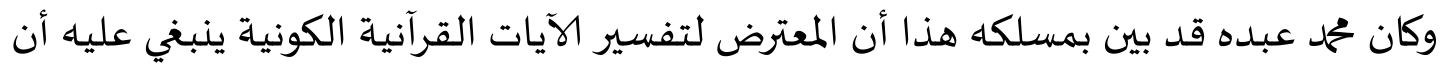

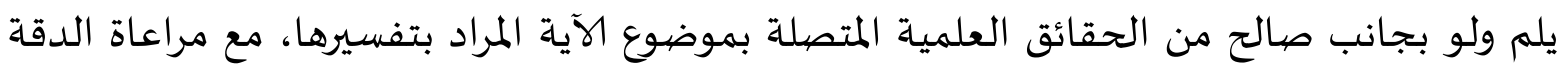

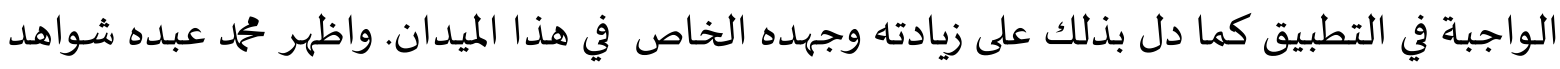

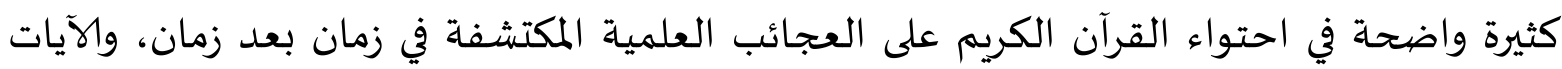

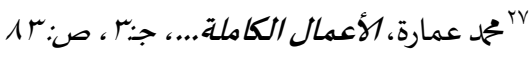

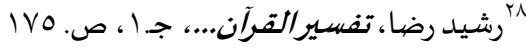

Teosofia: Indonesian Journal of Islamic Mysticism, Volume 5, Number 1, 2016 
الجامعة لأدق قواعد العلوم الكونية والطبيعية وغيرها، مثل قوله تعالى: "وأرسلنا الرياح لواقع"، وَفأورد تعاليق على كثير من المفسرين حيث كانوا يقولون فياء: "إنه تشبياء لتأثير الرياح الباردة في السحاب بما

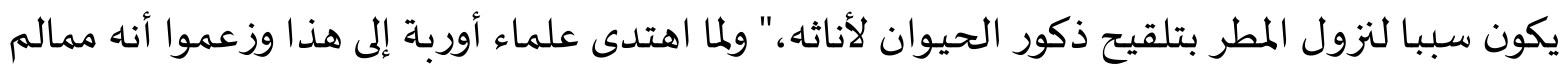
يسبقوا إليه من العلم صرح بعض المطلعين على القرآن منهم بسبق العرب إليه. قال مستر أجنيري

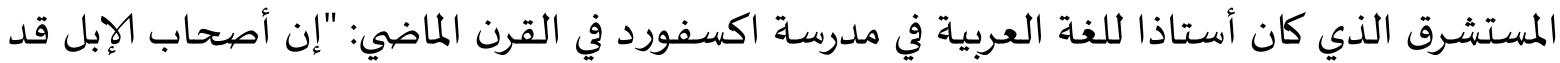

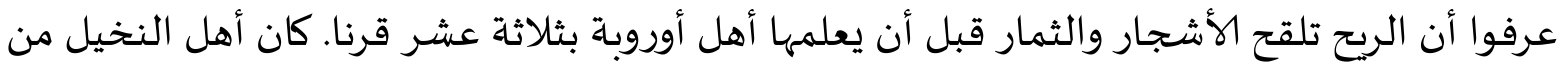
العرب كانوا يعرفون التلقيح إذا كانوا ينقلون بأيديهم اللقاح من طلع ذكور النخل إى إناثها، ولكنهم لم يكونوا يعلمون أن الرياح تفعل ذلك، ولم يفهم المفسرون هذا من الآية بل حملوها على المجاز. ثم بيّن

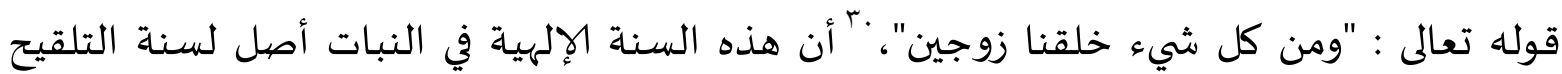

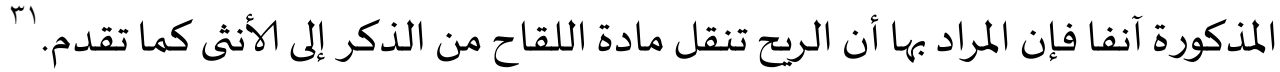

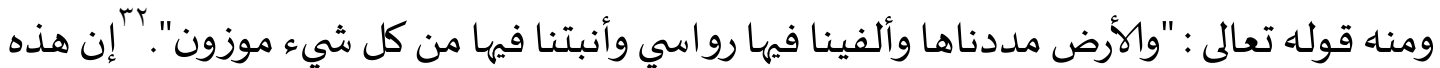
الآية هي أكبر مثال للعجب بهذا التعبير (موزون) فإن علماء الكون الأخصائيين في علوم الكيمياء والنبات قد أثبتوا أن العناصير التى يتكون منها النبات مؤلوفة من مقادير معينة في كل نوع من أنواعاء بدقة غريبة لا يمكن ضبطها إلا بأدق الموازين المقدرة من أعشار الغرام والمليغرام، وكذلك نسبة بعضها إلى بعض في كل نبات. وقال محمد عبده : إن هذا التعبير بلفظ "كل" المضاف إلى لفظ "شيء" الذي هو أعم الألفاظ العربية الموصوف بالموزون- تحقيق لمسـائل علمية فنية لم يكن شيء منها يخطر ببال بشر قبل

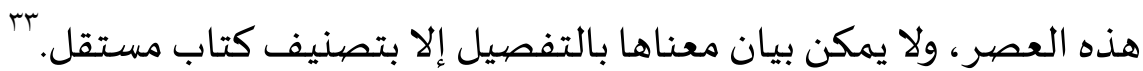

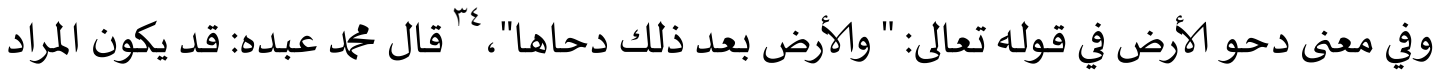

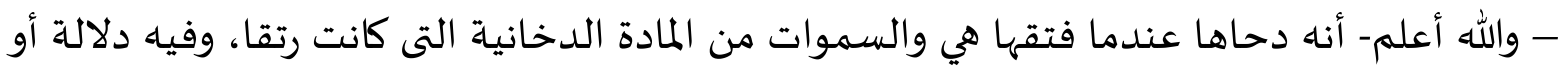
إشارة أهها كرة أو كالكرة في الاستدارة، ولا يبعد أن يكون المراد بدحوها ودخرجتها حركتها بقدرته تعالى في

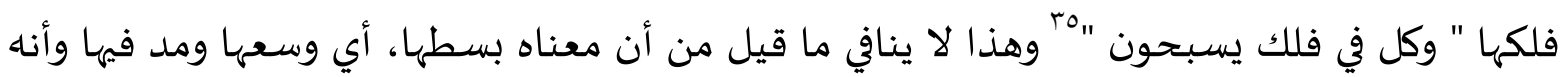

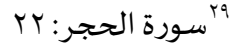

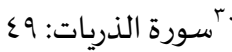

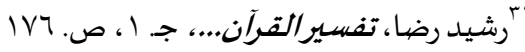

$$
\begin{aligned}
& \text { rا بسورة الحجر:19 } \\
& \text { V' V }
\end{aligned}
$$

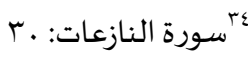

$$
\begin{aligned}
& \text { ("سورة يس: .ع ع }
\end{aligned}
$$


سطحها، أي جعل لها سطحا واسعا يعيش عليه الناس وغيرهم، فمن جعل مسألة كرويتها وسطحها

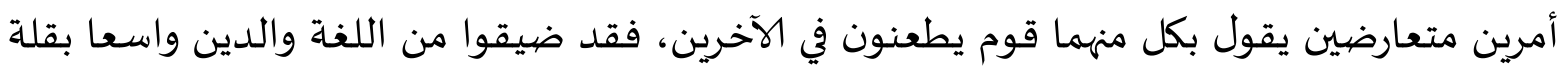
بضاعتهم فيها معا. ولا يذهب محمد عبده بعيدا بهذا القول، فإن الله خاطب العرب في قرآنه بما تفهماه عقولهم وقت

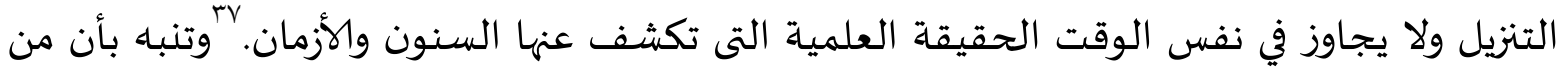
المفسرين من اهتم بهذا ومنهم من غفل، فصرف اللفظ عن حقيقته التى كشفت عنها العلوم الحديثة-

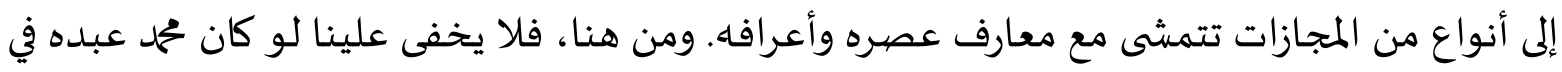
دعوته إلى فكرة التفسير العلمي مثالا في معرضها الحديث عن اعجاز القرآن.

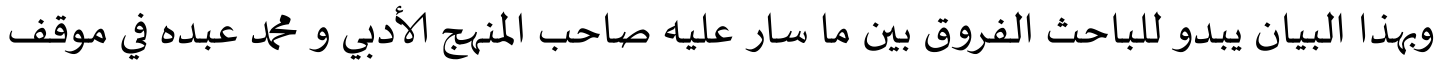

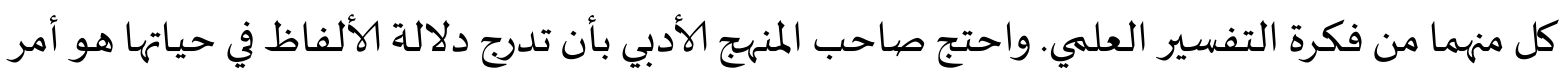

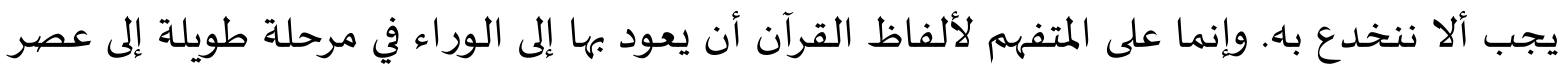

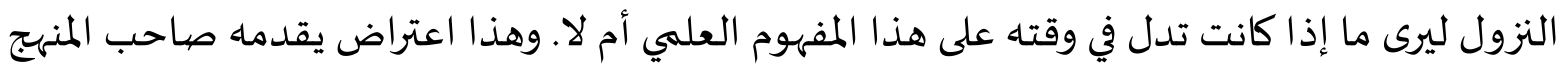

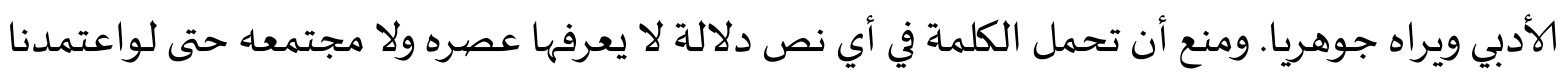

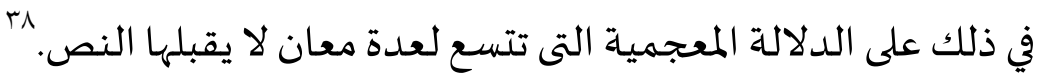

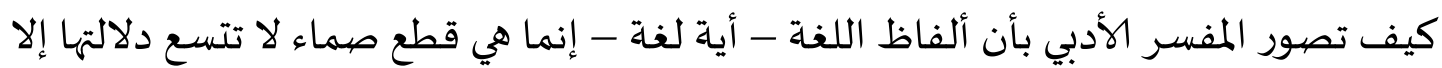

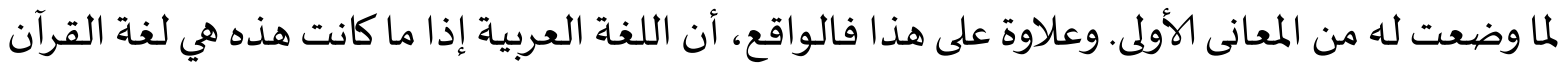

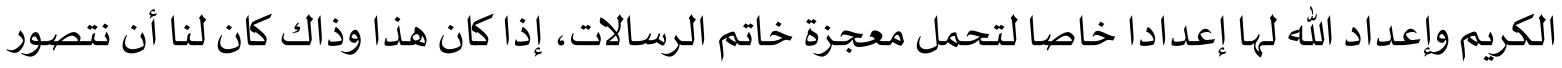

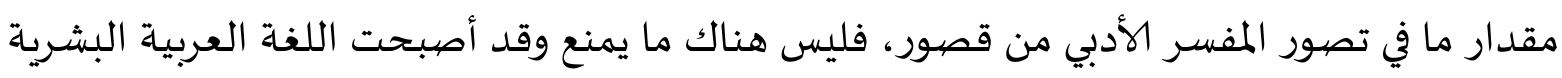

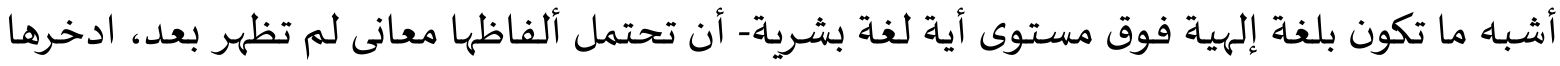

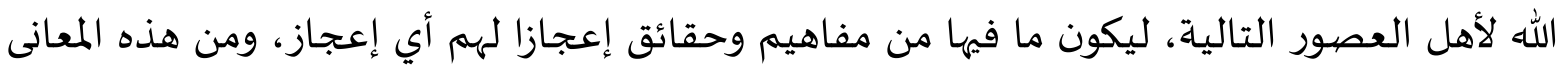
والمفاهيم ما يحصل عليه المفسر العلمي في ضوء الحقائق العلمية اليقينية.

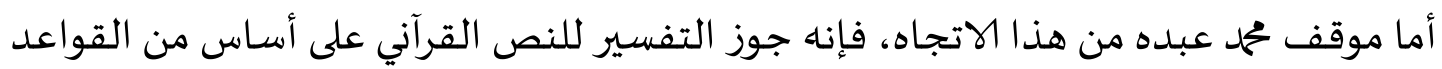

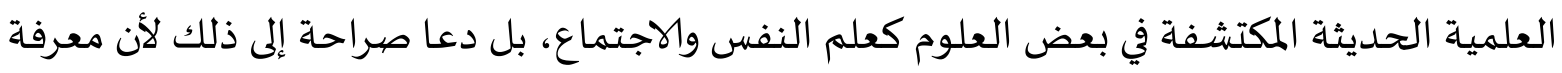

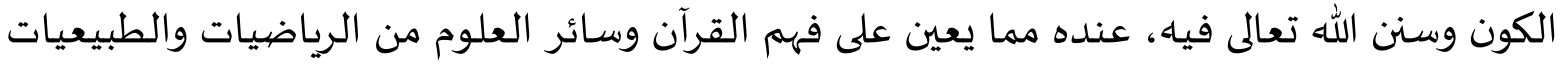

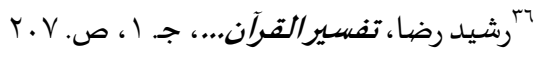

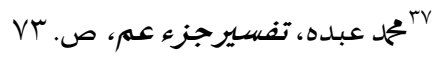

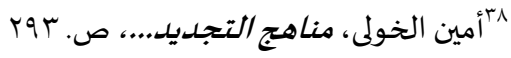

Teosofia: Indonesian Journal of Islamic Mysticism, Volume 5, Number 1, 2016 
وغيرها، لا يضر شيء منها بالدين، بل يقويها كما انها تقويه،، جّ، كما أن القرآن الكريم موافق لما يتجدد من العلم الحق والتشريع العدل أوغير مخالف لله. فلا بد من أن يكون اعجازه مما يعجز الزمان عن

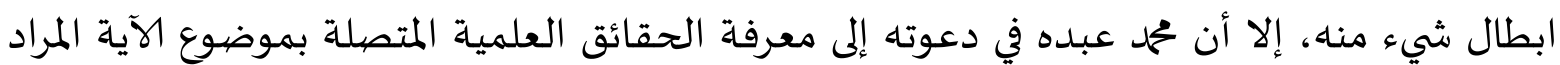
بتفسيرها، قد تنباء على أن يكون هذا العمل مع مراعاة الدقة الواجباة في التطبيق، بأن لا يكون التفسير يتجاوز عن دلالة المعنى المراد في القرآن فيبتعد المفسرعن الاقحام في تفسير آيات القرآن الكريم. وكانت قاعدة السياق كفاية لمحمد عبده في تحليل معان ألفاظ القرآن من حيث استعمالاتها مع الاحتراس مما طرأ على معانيها من تطور واستعمالات.

\section{و. محمد عبده وفكرة التمثيل}

وقد استخذم محمد عبده فكرة التمثيل في التفسير فيما يكشف -فحسب- عن أهداف القرآن وغايتاء، وهي تربية الإنسان سلوكا واعتقادا، أو بمعنى أدق هداية الإنسان وإرشاده إلى طريق الخير والبر، وتوجيها إلى الارتفاع بالحياة التى يعيشها الناس من حوله. ولنعرف كيف طبق محمد عبده فكرة التمثيل التى ربما تتميز عن بقية المفسرين، لا سيما حينما طبقها في تفسير القرآن على ضوء المهي المبداء الأساسي في التفسير الذي سار علياه محمل عبده في تفسير القرآن الكريم. وعلى امكان الباحث أن نأخذ من بعض الأمثلة المتعلق بتفسيره الأدبي.

وقد اتخذ محمد عبده فكرة التمثيل أمثل أسـاليب البلاغة وأشدها تأثيرا في النفس وإقناعا للعقل، كما دلّ عليه النص (سورة العنكبوت: عץ ). وقد بين هذا عبد القاهر الجرجاني في تأثير التمثيل سبابه وعلته أن له أسبابا وعللا، كل منها يقتضي أن يفخم المعنى بالتمثيل وينبل, ويشرف ويكمل، فأول ذلك وأظهره أن أنس النفوس موقوف على أن تخرجها من خفي إلى جلي، وتأتيها بصريح بعد مكني، وأن تردها في الثيء تعلمها إياه إلى أي شيء آخر هي بشأنه أعلم، وثقتها باه في المعرفة أحكم، نحو أن تنقلها عن إن إنها

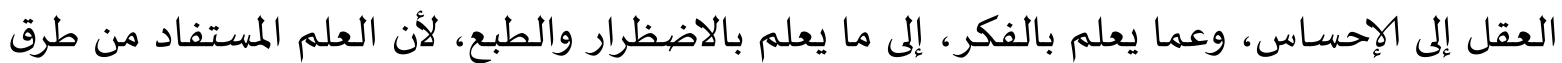
الحواس أو المركوز فهها من جهة الطبع وعلى حد الضرورة يفضل المستفاد من جهة النظر والفكر في

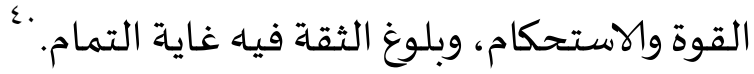
وإذا أمعنا النظر إلى تفسير محمد عبده فبان لنا أنها استمد من بيان عبد القاهر الجرجاني في كتابه (أسرار البلاغة) لأجل وفاه حقاه من البيان المقنع، فهاك رشيد رضيا ما كتب في هذا المثل ثم بعده

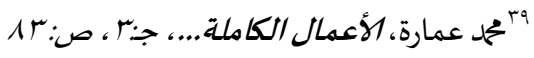

$$
\begin{aligned}
& \text { •عبد القاهر الجرجاني، أسرار/البلاغة.... ص. } 1 \text {. } 1 .
\end{aligned}
$$


إجمالا ثم تفصيلا، مقتبسا معانيه من دروس أستاذه، محمد عبده، بيد أنه بجانب إلى استمداده برأي عبد

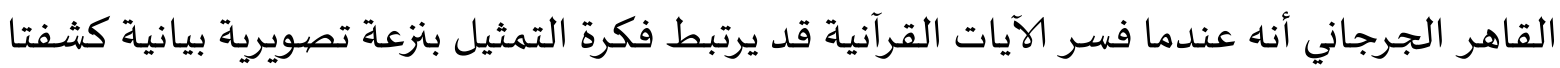

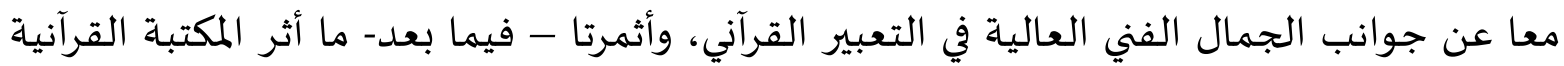

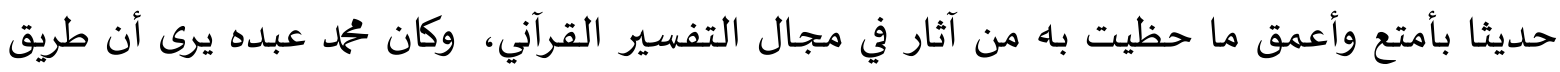

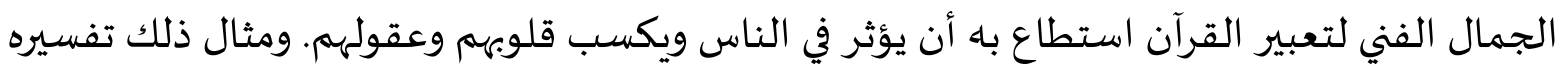

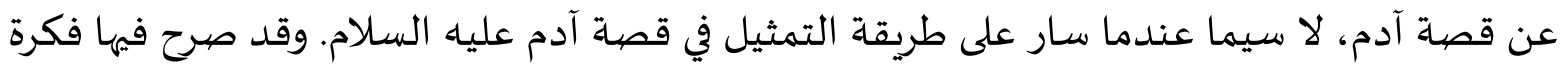

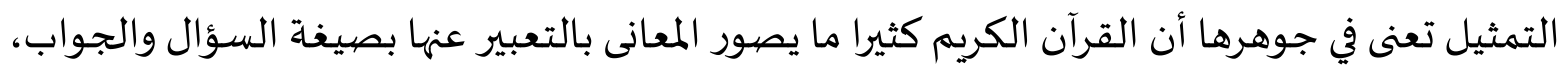

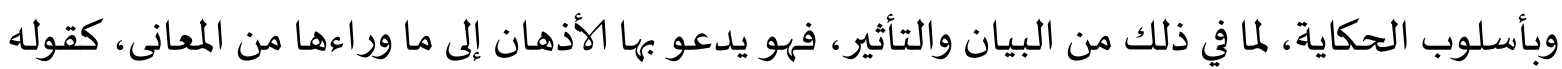

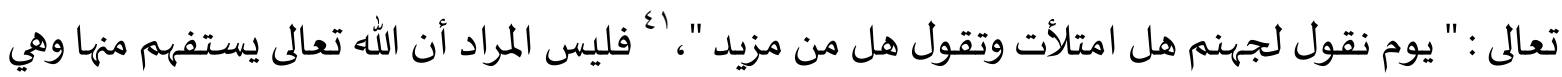

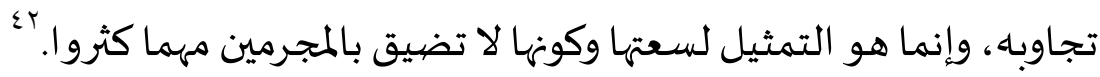
وقرر محمد عبده نزعة التصوير عند تعرضها لتفسير الآيات الكريمة " وعلم الآدم الأسماء كلها "

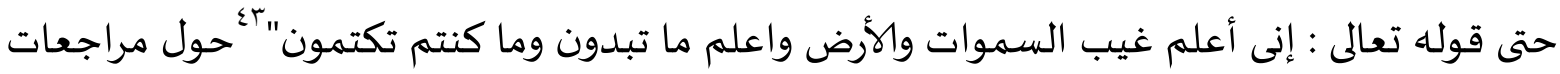

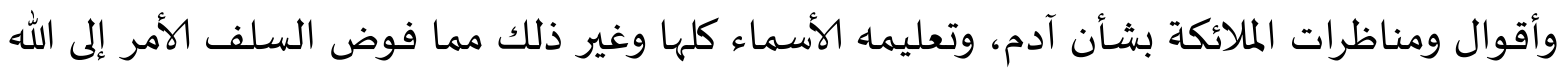

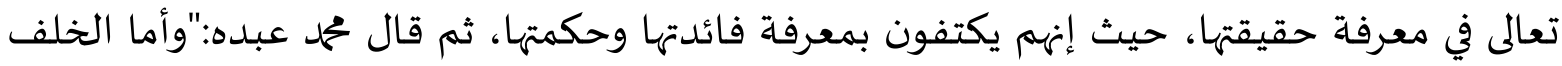

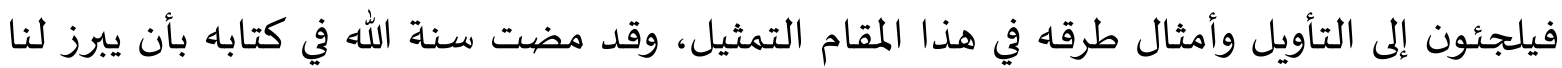
الأشياء المعنوية في قوالب العبارة اللفظية، ويجلى لنا المعارف المعقولة بالصور فئال تقريبا للأفهام وتسهيلا

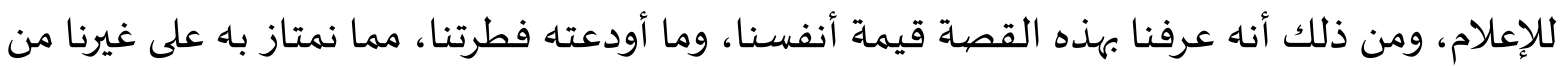
المخلوقات، فعلينا أن نجتهد في تكميل أنفسنا بالعلوم التى خلقنا مستعدين لها من دون الملائكة بفضلها فيلها ومعنى سجودهم لأصلنا.

وصرح محمد عبده بأن أمر الخلقة وكيفية التكوين في تلك الأية من الشؤون الإلهية التى يعز الوقوف علهيا كما هي, وقد قص علينا في هذه الآيأت خبرة النشأة الإنسانية على نحو ما يؤثر عن أهل

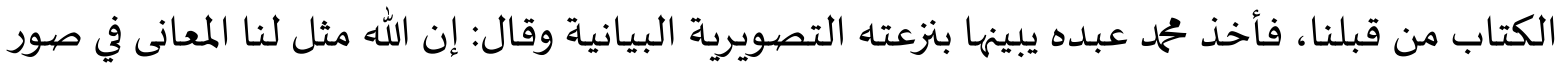
محسوسة، وأبرز لنا الحكم والأسرار بأسلوب المناظرة والحوار، كما هي سنته في مخاطبة الخلق، وبيان

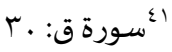

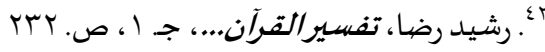

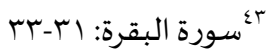

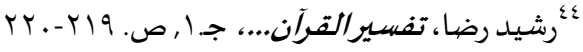

Teosofia: Indonesian Journal of Islamic Mysticism, Volume 5, Number 1, 2016 
الحق. ومن هنا، ذهب إلى أن هذه الآيات من المتشابهات التى لا يمكن حملها على ظاهرها، لأناه بحسب قانون التخاطب إما استشارة، وذلك محال على الله تعالى، واما إخباره منه سبحانه وتعالى للملائكة

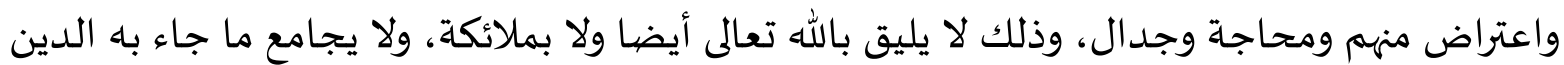

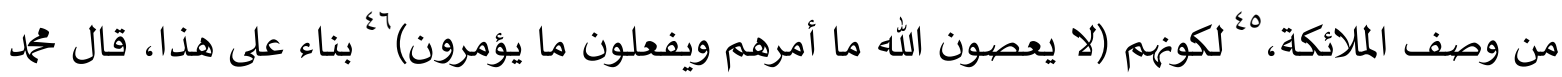
عبده:"إن كل قول أو فعل ينسب إلى من لا يصدر عنـه في المعروف فنسبتـا إليه على طريق التمثيل إلا أن

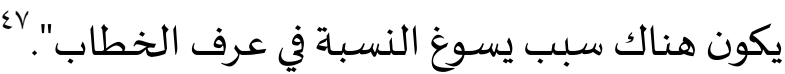
وذهب محمد عبده في تقرير التمثيل في قصة آدم إلى أن فيها صور عبر وهي : إن أخبار الله الملائكة بجعل الإنسان خليفة في الأرض هو عبارة عن تهيئة الأرض وقوى هذا العالم وأرواحه التى بها قوامها ونظامها إنها لوجود نوع من المخلوقات يتصرف فيها فيكون باه كمال الوجود في هذه الأرض - وسؤال الملائكة عن

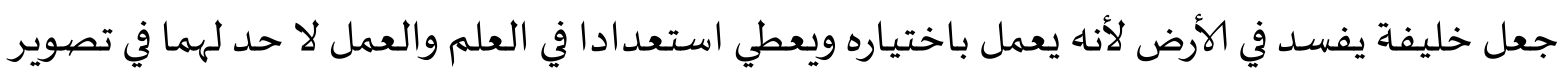
لما في استعداد الإنسان لذلك وتمهيد لبيان أنه لا ينافي خلافته في الأرض- وتعليم آدم الأسماء على الملائكة وسؤالهم عنها وتنصلهم في الجواب تصوير لكون الشعور الذي يصاحب كل روح من الأرواح المدبرة للعلوالم محدودا لا يتعدى وظيفتاه- وسجود الملائكة لآدم عبارة عن تسخير هذه الأرواح والقوى له ينتفع بها في ترقية الكون بمعرفة سنن الله تعالى في ذلك- وإباء إبليس واستكباره عن السجود تمثيل لعجز الإنسان عن إخضاع روح الشر وإبطال داعية خواطر السوء التى هي مثار التنازع والتخاصهم، والتعدي

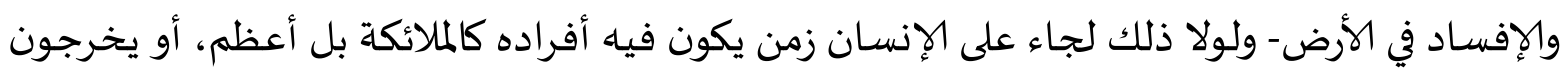
عن كونهم من هذا النوع البشري. ^؛ ومن ذلك كله خير الدليل على أن محمد عبده قد ارتبط فكرة التمثيل بنزعة تصورية بيانية ولم يكن من المفسرين الذين يفسرون هذه الآيات على طريقة التمثيل إلا تفسير إني ابن كثير. هذا كما أشار إليه رشيد رضيا في بيان أن قصاة آدم عند محمد عبده هو أمر التكوين. ونكتفى هنا بما قاله محمد عبده نفسـه - بعد نقل طريقة السلف في التنزياء والتفويض في المتشـاباه وطرق الخلف في التأويل : - وأنا على طريقة السلف في وجوب التسليم والتفويض فيما يتعلق بالله تعالى وصفاته وعالم الغيب، وأننا نسير في فهم الآيات على كلتا الطريقتين ، لأنه لا بد للكلام من فائدة يحمل

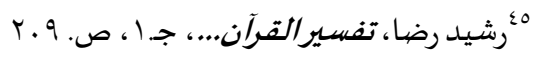

$$
\begin{aligned}
& \text { 7"سورة التحريم: } 7
\end{aligned}
$$

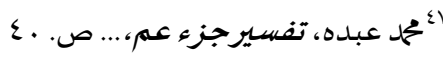

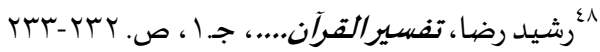


عليها، لأن الله عز وجل لم يخاطب بما لا نستفيد مناه معنى وَفهذا هو موقف محمد عبده من موازنة الاعتماد على البرهان النقلي والبرهان العقلي في مسائل العقيدة، فكانت هي الأصل المحكم في الاعتقاد الذي يجب أن يرد إلياء غيره، وهو التنزيه. فإذا جاء في نصوص الكتاب أو السنة شيء ينافي ظاهرة التنزياء فللمسلمين طريقتان: إحداهما؛ طريقة السلف وهي التنزيه الذي أيد بالعقل فياء النقل كقوله تعالى ( ليس كمثله شيء)، “وتفويض الأمر إلى الله تعالى في حقيقة ذلك، مع العلم بأن الله يعلمنا بمضيون كلامه إهـ ما نستفيد باه في أخلاقنا وأعمالنا وأحوالنا، ويأتينا في ذلك بما يقرب المعانى من عقولنا ويصورها لمخيلاتنا. والثانية؛ طريقة الخلف وهي التأويل، ويقولون إن قواعد الدين الإسلامي وضعت على أسـاس العقل فلا يخرج شيء منها عن المعقول فإذا جزم العقل بشيء وورد في النقل خلافه يكون الحكم العقلي القاطع قرينة على أن النقل لا يراد باه ظاهره ولا بد لله من معنى موافق يحمل عليه، فينبغي طلبه بالتأويل. وذلك لأن محمد عبده لقد آمن بأن الوحي والعقل كليهما أثر من آثار الله في الوجود، كما أن كليهما مصدر هداية، ويهدف إلى تحديد الطريق المستقيم للإنسان في الحياة، فمن الضروري انسجامهما وتعاونهما في تحقيق رسالتهما، ومن هنا، كان استخدام محمد عبده للعقل - لا كما استخدماء المعتزلة في تأييد عقائدهم ومذهبهم - بل في تقريب الإسلام وأفكاره من العلماء المحدثين الذين لا يؤمنون إلا بما تقبله عقولهم وما تسلم باه مناهجهم.

ويتضح من تتبع آثار محمد عبده التفسيرية أنه فيما ذهب إليها من التحليل البياني فيما كان موضوع خلاف من الآيات والتجائه في اقناع غير المؤمنين بحقائق الغيب والدين. - إلى التوسع في المجاز

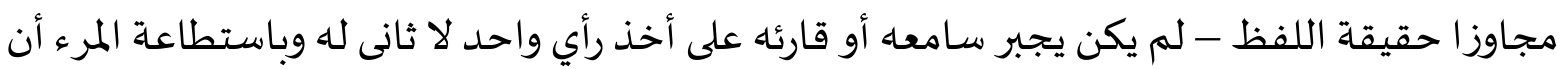
يتلمس ذلك واضحا فيما ساقه محمد عبده من آراء خاصاة حول مفهوم الملائكة اتبعها بأقوال غيره من المفسرين.

ومن هنا، فالباحث لا يتفق مع من يرى أن لمحمد عبده نزعة اعتزالية عقدية. بل إن محاولته للكشف للأمور الغيبية بفكرة التمثيل في تفسيره خير الدليل على نزعتاه العقلية في تأويل النصوص

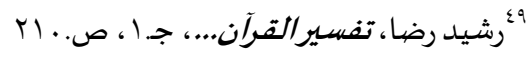

$$
\begin{aligned}
& \text {. }
\end{aligned}
$$

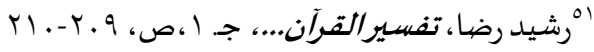

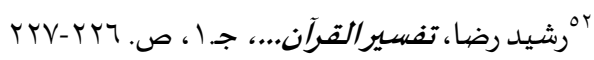

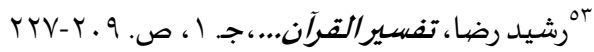

Teosofia: Indonesian Journal of Islamic Mysticism, Volume 5, Number 1, 2016 
القرآنية وتأثره بالبلاغيين القدامى وعلى رأسهم عبد القاهر الجرجاني والزمخشري، فإن مثل هذا الزعم لا يجد له سندا ولا أساسا، فضلا عن أنه يناقض تحذير محمد عبده من الدخول في فهم القرآن بعد

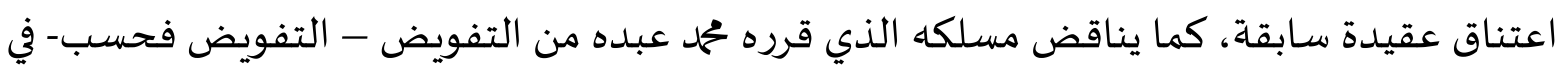

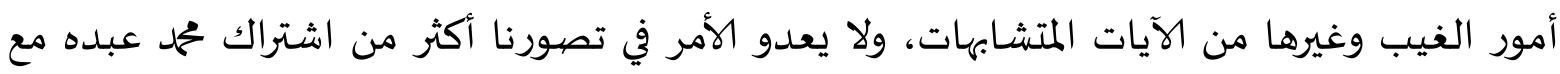
المعتزلة في الإعلاء من شأن العقل واستخداماء بحرية في التأويل والتمثيل، مع اختلافهم في الغاية والهدف من هذه الحرية العقلية.

ز. نتيجة البحث

يتوصل الباحث إلى نتيجة هذا البحث, أن اتجاه محمد عبده الأدبي في تفسير الآيات القرآنية كان يسير على الاتجاه الأدبي في التفسير الحديث. ويبرهن ذلك باعتماده على الدراسـة ما في النص عند ما قام

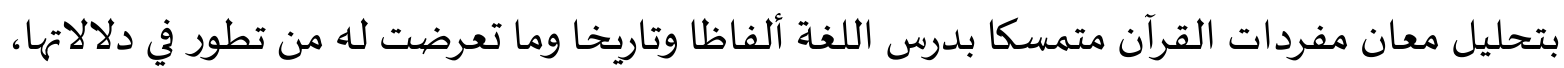

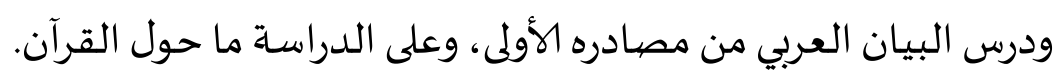

واتخذ محمد عبده الفكرة التى يحددها السياق قاعدة في فهم معانى مفردات القرآن. واتسع بها في التفسير مع مراعاة الدقة الواجبة في التطبيق، بأن لا يكون التفسير متجاوزا واقحاما عن دلالة المعنى المراد في القرآن نفسـاء. ودعا صراحة إلى معرفة الحقائق العلمية المتصلة بموضوع الآية المراد بتفسيرها،لأها لا يضر شيء منها بالدين، بل يقويها كما انها تقويه، بل كان عنده برهانا على اعجازه

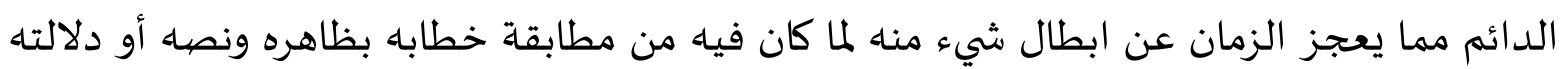
الأولى لمقتضى حالهم وقت نزول القرآن وما يعرفون، وبما احتواه باطن خطابه أو بدلالاته الثانوية لمن بعدهم مدى العصور. واستخدم محمد عبده فكرة التمثيل في التفسير فيما يكشف عن أهداف القرآن وغايته، وهي تربية الإنسان سلوكا واعتقادا، وهي عنده أمثل أساليب البلاغة وأشدها تأثيرا في النفس وإقناعا للعقل لا سيما عندما طبقها في الكشف للأمور الغيبية حتى وصبل إلى نزعته عقلية الإسيان في تأويل النصيوص القرآنية المتميزة عن المعتزلة. 


\section{المراجع}

إبراهيه، محمد أبو الفضل ، البرهان في علوم القرآن، القاهرة: مكتبة دار التراث، عـ9 ام، طـ م. البقاعي، أبو بكر، نظم الدررفي تناسب الوايات والسور، السمرقندي: دار العلوم.

الخالدي، الصلاح عبد الفتاح، مع قصص السابقين في القرآن، دمشق: دار القلم، 1997 م. م.

الديلمي الهمذاني، أبو شجاع شيرويها بن شهردار، الفردوس بهأثور الخطاب، تحقيق السعيد بن بسـوني

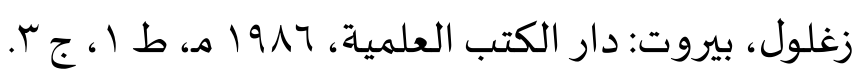

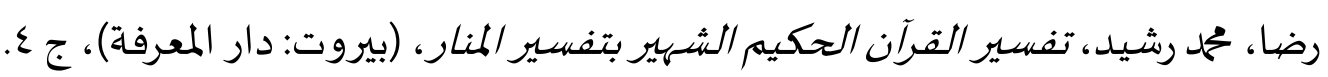

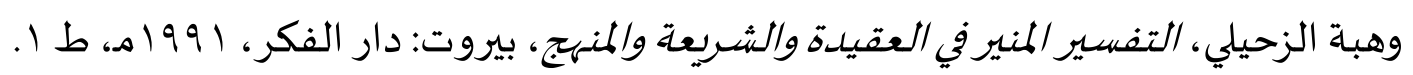

Khoiru an-Nahdiyyin, Metode Tafsir Sastra, Yogyakarta: Adab Press, 2004.

M. Nurkholis Setiawan, Al-Qur'an Kitab Sastra Terbesar, Yogyakarta: eLSAQ Press, 2005. 
